\title{
Wie willen werkgevers? : personeelsselectie in de zorg, de metaalindustrie en de IT
}

Citation for published version (APA):

Smits, W. (2001). Wie willen werkgevers? : personeelsselectie in de zorg, de metaalindustrie en de IT. Researchcentrum voor Onderwijs en Arbeidsmarkt, Faculteit der Economische Wetenschappen. ROA Working Papers No. 2 https://doi.org/10.26481/umarow.2001002

Document status and date:

Published: 01/01/2001

DOI:

10.26481/umarow.2001002

Document Version:

Publisher's PDF, also known as Version of record

\section{Please check the document version of this publication:}

- A submitted manuscript is the version of the article upon submission and before peer-review. There can be important differences between the submitted version and the official published version of record.

People interested in the research are advised to contact the author for the final version of the publication, or visit the DOI to the publisher's website.

- The final author version and the galley proof are versions of the publication after peer review.

- The final published version features the final layout of the paper including the volume, issue and page numbers.

Link to publication

\footnotetext{
General rights rights.

- You may freely distribute the URL identifying the publication in the public portal. please follow below link for the End User Agreement:

www.umlib.nl/taverne-license

Take down policy

If you believe that this document breaches copyright please contact us at:

repository@maastrichtuniversity.nl

providing details and we will investigate your claim.
}

Copyright and moral rights for the publications made accessible in the public portal are retained by the authors and/or other copyright owners and it is a condition of accessing publications that users recognise and abide by the legal requirements associated with these

- Users may download and print one copy of any publication from the public portal for the purpose of private study or research.

- You may not further distribute the material or use it for any profit-making activity or commercial gain

If the publication is distributed under the terms of Article $25 \mathrm{fa}$ of the Dutch Copyright Act, indicated by the "Taverne" license above, 
Wie willen werkgevers?

Personeelsselectie in de Zorg, de Metaalindustrie en de IT

ROA-W-2001/2

Wendy Smits

Researchcentrum voor Onderwijs en Arbeidsmarkt

Faculteit der Economische Wetenschappen en Bedrijfskunde

Universiteit Maastricht

Maastricht, juli 2001 
ISBN 90-5321-313-9

Sec01.232 
Inhoud

Bladzijde

Voorwoord

1 Inleiding 1

2 Het vignetonderzoek 2

3 Het empirische model $\quad 7$

4 De resultaten 10

5 Betekenis voor het project Onderwijs-Arbeidsmarkt $\quad 17$

6 Conclusies 20

Literatuur 21

Bijlage A: Schattingsresultaten 23

Bijlage B: Functieomschrijvingen 33

Bijlage C: Kansverdeling opleiding en vorige beroep 37

Bijlage D: Vragenlijst 



\section{Voorwoord}

In dit werkdocument worden de resultaten besproken van een vignetonderzoek onder werkgevers in de IT, de Metaal en de Zorg, en wordt aangegeven hoe deze resultaten kunnen worden aangewend voor de verdere ontwikkeling van het Project Onderwijs Arbeidsmarkt (POA). De projectleiding van het onderzoek was in handen van drs. W. Smits. Aan het vignetonderzoek is verder meegewerkt door dr. J.D. Vlasblom, drs. J.M.A.F. Sanders en drs. J. Schreurs. Het veldwerk is uitgevoerd door J.R. Baars en E. Peeters. Verder zijn wij dank verschuldigd aan drs. L. Zwiers van de Limburgse Werkgevers Vereniging (LWV) voor de aanbeveling van het onderzoek onder de leden van het LWV.

Dit werkdocument maakt deel uit van het Project Onderwijs Arbeidsmarkt (POA). Dit Project wordt gefinancierd door het Ministerie van Onderwijs, Cultuur en Wetenschappen, Arbeidsvoorziening Basisdiensten, het LDC Expertisecentrum voor Loopbaanvraagstukken en het Ministerie van Landbouw, Natuurbeheer en Visserij. 


\section{Inleiding}

Vraag en aanbod op de arbeidsmarkt worden vaak vanuit verschillende invalshoeken geanalyseerd. Voor de vraag naar arbeid is de dimensie beroep veelal het meest toereikend. Een beroep kan worden getypeerd als een bundeling van werkzaamheden. Om deze werkzaamheden goed uit te kunnen voeren zijn bepaalde kennis en vaardigheden nodig. De vraag naar arbeid voor een bepaald beroep kan daarom ook gezien worden als vraag naar bepaalde kennis en vaardigheden. Het aanbod wordt meestal geanalyseerd vanuit de invalshoek opleiding. Opleiding is echter een onvolledige indicator voor het menselijk kapitaal van een individu. Veel kennis en vaardigheden kunnen immers niet alleen tijdens de opleiding maar ook in de praktijk worden opgedaan. Daarnaast zijn er ook verschillende vaardigheden die vrijwel alleen maar in de praktijk kunnen worden opgedaan, denk daarbij bijvoorbeeld aan leiding geven, het omgaan met collega's, het plannen en organiseren van het werk etc. Bovendien kunnen mensen competenties na het verlaten van de opleiding weer (gedeeltelijk) verliezen wanneer deze lange tijd niet benut worden. Tenslotte wordt een deel van het menselijk kapitaal dat van belang is voor het uitoefenen van een beroep noch in de schoolbanken noch door werkervaring opgedaan. Uiterlijke schoonheid is bijvoorbeeld in veel beroepen van belang evenals fysieke kracht.

Door een te eenzijdige fixatie op opleiding als maatstaf voor kennis en vaardigheden bij de analyse van knelpunten blijft een deel van de aansluitingsproblematiek onderbelicht. In het informatiesysteem Onderwijs-Arbeidsmarkt heeft de nadruk echter altijd voornamelijk op de dimensie opleiding gelegen. Dit heeft vooral te maken met het oorspronkelijke doel van het informatiesysteem; namelijk het genereren van informatie ten behoeve van de studie- en beroepskeuzevoorlichting van jongeren. In de loop der jaren is het aantal gebruiksdoelen van het informatiesysteem echter toegenomen. Voorbeelden hiervan zijn analyses van knelpunten in de personeelsvoorziening ten behoeve van werkgevers en analyses van baankansen van andere aanbodcategorieën op de arbeidsmarkt, zoals werklozen en herintreders. Meer inzicht in het belang van andere factoren dan het gevolgde onderwijs, zoals werkervaring, inactiviteit en persoonlijke kenmerken is daarom van grote waarde voor het project Onderwijs-Arbeidsmarkt.

In dit onderzoek wordt getracht het relatieve belang van al deze factoren te meten door te kijken naar werkgeversvoorkeuren met betrekking tot kandidaten voor verschillende beroepen. Het onderzoek richt zich op werkgevers in drie onderling sterk verschillende bedrijfssectoren, namelijk de IT, de Zorg en de Metaal. De IT is een sector waarin zeer complexe vaardigheden vereist worden die bovendien door de snelle technologische ontwikkelingen snel weer verouderen. De relatie tussen opleiding en beroep is in deze sector relatief zwak (Smits e.a., 1997). De Zorg is een zeer arbeidsintensieve sector, waar scholingveroudering veel minder een rol speelt maar waar daarentegen de formele opleidingseisen voor de verschillende functies zeer belangrijk zijn. Verder wordt de zorgsector getypeerd door het hoge percentage vrouwen dat in de sector werkzaam is (ROA, 1999b). In de Metaal is het percentage vrouwen daarentegen erg laag. In tegenstelling tot beide overige sectoren is de werkgelegenheid in de Metaal zeer conjunctuurgevoelig. Verwacht mag worden dat genoemde sectorkenmerken ook tot uiting 
komen in de werkgeversvoorkeuren met betrekking tot personeel voor verschillenden functies.

Voor het onderzoek is gebruik gemaakt van de zogenaamde vignetmethode. Deze methode houdt in dat respondenten een aantal profielen (vignetten) van fictieve kandidaten voorgelegd krijgen en die dan vervolgens moeten rangschikken op basis van hun voorkeur. De respondent is doorgaans diegene in het bedrijf die zich gewoonlijk met de selectie van personeel bezig houdt, meestal de personeelsfunctionaris of de eigenaar. De fictieve kandidaten verschillen met betrekking tot persoonlijke kenmerken, opleidingsachtergrond en werkverleden. Door middel van dit vignetonderzoek is een grote hoeveelheid data verzameld over de voorkeuren van werkgevers met betrekking tot mogelijke kandidaten voor een groot aantal functies. Deze dataset maakt het mogelijk om, gegeven het arbeidsaanbod, het relatieve effect van opleiding, werkervaring, werkloosheid en inactiviteit op de werkgeversvoorkeuren te toetsen.

Dit paper is verder als volgt opgebouwd. Paragraaf 2 beschrijt de opzet van het vignetonderzoek. Paragraaf 3 gaat vervolgens in op het empirische model en in paragraaf 4 worden de belangrijkste resultaten gepresenteerd. In paragraaf 5 wordt aangegeven wat deze resultaten betekenen voor de verschillende onderdelen van het project OnderwijsArbeidsmarkt, in het bijzonder voor de knelpuntenindicator per beroepsgroep. Paragraaf 6 sluit af met enkele conclusies.

\section{Het vignetonderzoek}

Bestaande databronnen geven slechts een onvolledig beeld van de voorkeuren van werkgevers met betrekking tot verschillende kandidaten voor een vacature. We nemen meestal wel waar welke kandidaten worden aangenomen maar weten weinig of niets van de overige kandidaten. Informatie over de overige kandidaten is echter van wezenlijk belang om te bepalen op basis van welke criteria kandidaten uiteindelijk worden geselecteerd en in welke mate deze criteria vast liggen of worden aangepast aan de arbeidsmarktsituatie. Idealiter zou daarom zowel de vraag (de vacature) als het aanbod (de kandidaten voor de vacature) bestudeerd moeten worden. Dat betekent dat het gehele selectieproces zou moeten worden gevolgd. Een dergelijk onderzoek is echter te kostbaar om op grote schaal uit te voeren. Een alternatief is het vignetonderzoek. Werkgevers krijgen dan voor een specifieke functie een aantal gefingeerde kandidaten voorgelegd die verschillen wat betreft leeftijd, opleiding, werkervaring etc. en worden vervolgens gevraagd hun volgorde van preferentie aan te geven.

Vignetonderzoek vindt zijn oorsprong in marketingonderzoek maar is de laatste jaren ook in de sociale wetenschappen gemeengoed geworden. Van Beek e.a. (1996) maken gebruik van een grootschalig vignetonderzoek onder Nederlandse werkgevers om een beeld te krijgen van het selectiegedrag van werkgevers voor beroepen die weinig scholing vereisen. De Wolf en van der Velden (1999) maken eveneens gebruik van deze methode voor onderzoek naar het selectiegedrag van werkgevers met betrekking tot recent afgestudeerde sociologen. Zij maken daarbij onderscheid tussen verschillende soorten beleidsgerichte en 
onderzoeksgerichte beroepen. Het voordeel van vignetonderzoek boven bijvoorbeeld een enquête is dat het door de veelheid van profielkenmerken lastiger is om sociaal wenselijke antwoorden te geven. Verder sluit vignetonderzoek beter aan bij de dagelijkse praktijk dan een abstracte enquête over selectiegedrag. Bovendien is het mogelijk het aantal kenmerken meer te laten variëren dan in werkelijkheid het geval is.

\section{Tabel 2.1}

Functies per bedrijfssector

IT

Helpdeskmedewerker

Secretaresse/managementassistente

Programmeur

Projectmanager

Projectadviseur

Systeemontwerper

Zorg

Medisch Secretaresse

Helpende

Zieken- of bejaardenverzorgende

Medisch analist

Verpleegkundige

Activiteitenbegeleider

Afdelingshoofd zieken-, verzorgings- of verpleegtehuis

Metaal

(Boog)lasser

(Constructie)bankwerker

Bedrijfshoofd/Manager

Monteur

Secretaresse/managementassistente

Fijnbankwerker

Productiemedewerker

Het is belangrijk om op te merken welke veronderstellingen aan dit type onderzoek ten grondslag liggen. In de eerste plaats wordt impliciet verondersteld dat de lonen in een functie vastliggen. Als de lonen namelijk volledig zouden kunnen variëren met de profielkenmerken zouden werkgevers geen voorkeur voor het ene profiel boven het ander hebben omdat productiviteitverschillen volledig in de lonen tot uitdrukking komen. Een alternatieve methode is om werkgevers aan elk profiel het loon te laten toekennen. Dit sluit echter minder goed aan bij de Nederlandse praktijk waar lonen voor kandidaten in eenzelfde functie meestal niet oneindig kunnen variëren. In de tweede plaats veronderstellen we voor dit onderzoek dat voorkeuren van werkgevers alleen verband houden met de verwachte productiviteit van een kandidaat en niet met andere zaken. Deze veronderstelling is noodzakelijk omdat we op basis van dit onderzoek juist willen bepalen welke factoren de productiviteit in een functie bepalen. 
Het onderzoek richt zich op verschillende beroepen in drie bedrijfssectoren, de IT, de Zorg en de metaalsector. Voor elke bedrijfssector hebben we op basis van advertenties in dagbladen een aantal veel voorkomende functies geselecteerd. Daarbij hebben we een onderscheid gemaakt tussen sectorspecifieke functies en meer algemene functies. De algemene functies betroffen de functie secretaresse en een leidinggevende functie. Bovendien is getracht om de functies enigszins te laten variëren naar niveau. Tabel 2.1 geeft een overzicht van de functies per bedrijfssector ${ }^{1}$.

Vervolgens is per functie het profiel van de potentiële kandidaten vastgesteld. Voor het onderzoek zijn we met name geï nteresseerd in het effect van vooropleiding, werkervaring en huidige arbeidsmarktpositie. Het is echter van belang dat een profiel ook voldoende kenmerken bevat die het mogelijk maken dat een werkgever zich daadwerkelijk een beeld van de kandidaat kan vormen. Dat betekent dat er ook persoonlijke kenmerken zoals naam, sexe, leeftijd en hobby's aan het profiel worden toegevoegd. Aan de andere kant moet een profiel ook niet zoveel kenmerken bevatten dat de kandidaat het overzicht verliest en nog maar op een enkele kenmerk selecteert.

Idealiter zou de vooropleiding van de gefingeerde kandidaat onafhankelijk moeten worden vastgesteld van de vereiste opleiding voor de functie. De voorkeuren van werkgevers met betrekking tot opleiding moeten dan blijken uit de resultaten van het onderzoek. Dit heeft echter twee nadelen. Ten eerste is de range van mogelijke vooropleidingen zeer groot. Als de opleiding van de gefingeerde kandidaat volledig onafhankelijk van het beroep is bepaald zijn heel veel waarnemingen mogelijk om uitspraken te kunnen doen over de geprefereerde vooropleiding. Ten tweede krijgen de respondenten in dat geval zeer veel profielen voorgelegd die niet voldoen aan de (impliciete) opleidingeisen met als gevolg dat het onderzoek minder goed aansluit bij de dagelijkse praktijk en mogelijk tot minder bereidheid tot deelname leidt. Daarom is er voor gekozen om per beroep relevante en niet-relevante opleidingen te selecteren. De relevantie van een opleiding is bepaald op basis van advertentieteksten en op basis van de Enquête Beroepsbevolking van het CBS. Het aandeel van relevante opleidingen verschilt per beroep en bedrijfssector. In de Zorg komt het bijvoorbeeld in werkelijkheid nauwelijks voor dat er kandidaten worden aangenomen die geen relevante vooropleiding hebben. Om ook voor de zorgsector de profielen voldoende realistisch te houden is de trefkans van relevante vooropleidingen hier hoger genomen dan in de IT en de Metaal.

Met betrekking tot werkervaring wordt het totaal aantal jaren werkervaring gegeven en het aantal jaren werkervaring in het huidige of meest recente beroep. Voor het huidige of meest recente beroep geldt dezelfde argumentatie als voor opleiding. Voor de herkenbaarheid van de vignetten moet er enige afhankelijkheid zijn tussen het beroep waarvoor de gefingeerde kandidaat zich 'aanbiedt' en het beroep dat deze kandidaat eerder had. Relevante werkervaring (in hetzelfde of aanverwant) beroep heeft daarom een relatief hoge trefkans gekregen ten opzichte van niet relevante ervaring.

1. In de bijlage wordt voor elke functie een functieomschrijving gegeven. 
Om een beeld te krijgen van de voorkeuren van werkgevers met betrekking tot werkenden, schoolverlaters, werklozen en herintreders is de huidige arbeidsmarktpositie van kandidaten weergegeven. Deze kan zijn werkend, werkloos, huisvrouw/man en schoolgaand, studeert binnenkort af. Voor werklozen en huisvrouw/man wordt de duur van de inactiviteit aangegeven ${ }^{2}$. Kandidaten die inactief zijn kunnen overigens wel werkervaring hebben. In dat geval wordt zowel het beroep waarin men ervaring heeft als deze duur van de ervaring aangegeven.

Een overzicht van de belangrijkste profielkenmerken, de mogelijke waarden en kansverdeling wordt gegeven in de bijlage. Op basis van de profielkenmerken zijn vervolgens per functie vignetten gecreëerd. De kenmerken zijn op enkele uitzonderingen na onafhankelijk getrokken. De belangrijkste uitzondering betreft de leeftijd van de kandidaten. Deze is bepaald als som van de leeftijd bij afstuderen (afhankelijk van vooropleiding), het totaal aantal jaren werkervaring, en de totale duur van eventuele inactiviteit plus een random component variërend tussen plus en minus één jaar. Verder is voor de herkenbaarheid van de profielen de trefkans van de hobbies afhankelijk van het beroep genomen. Figuur 2.2 geeft twee voorbeeldvignetten.

Tabel 2.2

Voorbeeldvignetten

$\begin{array}{ll}\text { Functie: } & : \text { Helpdeskmedewerker } \\ \text { Naam } & : \text { John Gubbels } \\ \text { Geslacht } & : 28 \\ \text { Leeftijd } & : \text { Nederlands } \\ \text { Nationaliteit } & : \text { MAVO } \\ \text { Gevolgde opleiding } & : \text { Werkloos } \\ \text { Huidige bezigheid } & : 4 \text { jaar en } 6 \text { maanden } \\ \text { Werkloosheidsduur } & : \text { Vertegenwoordiger softwarebedrijf } \\ \text { Laatste werkkring } & : 7 \text { maanden } \\ \text { Ervaring in deze werkkring } & : 5 \text { jaar } \\ \text { Totale werkervaring } & : \text { Gitaarspelen } \\ \text { Hobby } & : \text { secretaresse } \\ & : \text { Judith Balendonk } \\ \text { Functie } & : \text { Vrouw } \\ \text { Naam } & : 23 \\ \text { Geslacht } & : \text { Nederlands } \\ \text { Leeftijd } & : \text { MBO Directiesecr./management assistent (via leerlingwezen) } \\ \text { Nationaliteit } & : \text { Huisvrouw } \\ \text { Gevolgde opleiding } & : 2 \text { jaar } \\ \text { Huidige bezigheid } & : \text { Nooit gewerkt } \\ \text { Huisvrouw duur } & : \text { Volleybal } \\ \text { Laatste werkkring } & \end{array}$

Het aantal profielen dat een respondent per functie moet beoordelen mag niet te groot zijn omdat het gevaar bestaat dat de respondent anders zijn concentratie verliest en de eerst aangereikte vignetten niet meer zo nauwkeurig bestudeert als de laatste. Er is daarom

2. Hier geldt een maximum van vijf jaar. 
gekozen voor 15 profielen per functie. De respondent legt eerst de 15 profielen op volgorde van voorkeur neer en geeft vervolgens aan wat het eerste profiel is dat niet meer acceptabel is voor de functie.

Tabel 2.3

Verdeling van de bedrijven over verschillende bedrijfsgrootteklassen

\begin{tabular}{lrcr}
\hline & & aantal werknemers \\
& $1-9$ & $10-99$ & $>100$ \\
& $\%$ & $\%$ & 26 \\
\hline IT & & & 80 \\
Zorg & 11 & 63 & 39 \\
Metaal & 0 & 20 & 50 \\
Totaal & 0 & 62 & \\
& 3 & 47 & \\
\hline
\end{tabular}

Het onderzoek heeft zich beperkt tot bedrijven in Limburg. Verwacht wordt dat er slechts weinig regionale verschillen in voorkeuren van werkgevers zullen bestaan. Weliswaar kan door verschillende regionale arbeidsmarktomstandigheden de feitelijke selectie in de ene regio anders zijn dan in de andere maar voor dit effect kan gecorrigeerd worden. De bedrijven zijn geselecteerd uit een bestand van de Limburgse werkgeversvereniging, die tevens haar leden een aanbevelingsbrief heeft gestuurd, en het adressenbestand van de Kamer van koophandel. Uiteindelijk hebben 69 bedrijven aan het onderzoek mee gedaan 26 bedrijven in de Metaal, 24 in de Zorg en 19 in de IT. Per bedrijf zijn telkens voor vier verschillende functies vignetten voorgelegd. Vooraf was geï nformeerd welke van de functies voor het betreffende bedrijf relevant was. De respondent was steeds die medewerker in het bedrijf die zich in de praktijk bezig houdt met werving en selectie, dit was vaak de personeelsfunctionaris en soms de directeur/eigenaar van het bedrijf. Het veldwerk heeft plaatsgevonden van juni tot en met augustus 2000.

$\mathrm{Na}$ afloop van de vignetprocedure zijn nog enkele aanvullende vragen gesteld over het bedrijf (zoals het aantal werknemers, het aantal vacatures, recente ontwikkelingen en verwachte toekomstige ontwikkelingen in het personeelsbestand) en de respondent (zoals functie, opleiding en leeftijd). De vragenlijst is te vinden in de bijlage.

Tabel 2.4

Functie van de respondent

\begin{tabular}{lrr}
\hline & Personeelsfunctionaris & Directeur/eigenaar \\
& $\%$ & $\%$ \\
\hline IT & 42 & 47 \\
Zorg & 80 & 0 \\
Metaal & 62 & 31 \\
Totaal & 63 & 24 \\
\hline
\end{tabular}


Tabel 2.3 geeft de verdeling van de deelnemende bedrijven over de bedrijfsgrootteklassen en tabel 2.4 geeft de verdeling over de twee meest voorkomende functies van de respondent.

\section{Het empirische model}

Voor de analyse van de resultaten van het vignetonderzoek maken we gebruik van de Rank Order and Acceptabilty (ROA) analysis van Van Beek e.a. (1997). Dit model omvat twee stappen. In de eerste stap wordt de rangorde van de profielen verklaard. Verondersteld wordt dat de respondenten de profielen rangschikken op basis van een kwaliteitsindicator die de beschikbare kennis en vaardigheden van kandidaten meet. Deze kwaliteitsindicator wordt echter niet direct waargenomen. Daar de rangorde van een profiel ook afhankelijk is van de andere profielen in de set hebben twee profielen uit verschillende sets met een zelfde rangorde niet per se de zelfde kwaliteit. Ook het verschil in kwaliteit tussen twee profielen met verschillende rangorde verschilt per set. Als eenvoudig weg lineaire regressie wordt toegepast met het rangnummer als de te verklaren variabele wordt met deze overwegingen geen rekening gehouden. Van Beek e.a. maken daarom gebruik van het rank ordered logit model. In dit model wordt de kans verklaard dat een profiel $r_{1}$ als eerste wordt gerangschikt gegeven de 14 overige profielen en het profiel $r_{2}$ als tweede wordt gerangschikt gegeven de 13 overgebleven profielen etc. Merk op dat de rangorde een herschikking van de oorspronkelijke nummering van de profielen, $r_{i}=j$ betekent dat profiel $j$ rangnummer $i$ heeft. De likelihood functie voor een rangorde $r_{1}, \ldots, r_{15}$ wordt gegeven door:

$$
L(\beta ; x)=\prod_{i=1}^{14} \frac{e^{\beta^{\prime} x_{r_{i}}}}{\sum_{j=i}^{m} e^{\beta^{\prime} x_{r_{j}}}}
$$

waar: $x_{i}$ : kenmerken van profiel $r_{i}$

$\beta$ : het effect van een kenmerk op de voorkeursvolgorde.

Als $\beta_{k}>0$ dan heeft kenmerk $k$ een positief effect op de kwaliteit van de kandidaat en daarmee op de kans om hoog in de rangorde te eindigen. Daar voor verschillende functies verschillende kennis en vaardigheden nodig zijn zal het effect van een profielkenmerk op de kwaliteit van het profiel verschillen tussen functies. De inhoud van een functie ligt echter zelden volledig vast en zal verschillen tussen bedrijven. Ook bedrijfskenmerken kunnen dus van invloed zijn op het belang van bepaalde profielkenmerken. Tenslotte kunnen verschillende respondenten, afhankelijk van bijvoorbeeld hun ervaring en opleidingsachtergrond voor eenzelfde functie een verschillend gewicht aan bepaalde profielkenmerken toekennen. We kunnen de parameters dus specificeren als een functie van beroeps-, bedrijfs- en respondentkenmerken in $z$ (zie ook Borghans e.a. 1999):

$$
\beta=\beta_{0}+\beta_{1} z
$$


Op basis van de parameterschattingen uit deze eerste stap van het model kan de kwaliteit van de verschillende profielen worden geschat.

$\hat{y}_{i}=\hat{\beta}^{\prime} x_{i}$

Vervolgens kan dan de kans worden berekend dat werkgevers een kandidaat met bepaalde kenmerken boven een andere kandidaat prefereren. De kans dat werkgevers een profiel $i$ prefereren boven een profiel $j$ wordt gegeven door (zie ook Van Beek e.a, 1997):

$P($ profiel $i)=\frac{1}{e^{y_{j}-y_{i}}}$

waar $y_{i}$ de kwaliteit van profiel i. Als deze kans gelijk is aan $50 \%$ zijn werkgevers indifferent tussen beide profielen. Bij een kans groter dan $50 \%$ heeft men de voorkeur voor kandidaat $\mathrm{i}$.

In de tweede stap kijken we naar de kans dat een bepaald profiel acceptabel wordt gevonden voor de functie. Deze kans is afhankelijk van de kwaliteit van de kandidaat en van beroeps-, bedrijfs- en respondentkenmerken. Daarnaast kan ook de gemiddelde kwaliteit van de kandidaten in een set een rol spelen. Het idee daarbij is dat als het arbeidsaanbod afneemt en de gemiddelde kwaliteit van kandidaten verslechtert werkgevers hun selectiecriteria aanpassen en minder streng gaan selecteren. We verwachten dus dat er een negatieve relatie is tussen de gemiddelde kwaliteit van een set en de kans dat een profiel acceptabel wordt gevonden. De gemiddelde kwaliteit per set volgt uit het rank-order model en wordt bepaald als het gemiddelde van de geschatte kwaliteit van alle afzonderlijke profielen in de set. De volgende logitspecificatie is geschat:

$P($ acceptabel $)=\frac{e^{\beta^{\prime} x+\delta^{\prime} z+\lambda \bar{y}}}{1+e^{\beta^{\prime} x+\delta^{\prime} z+\lambda \bar{y}}}$

waar: $\mathrm{x}$ : kenmerken van de kandidaat

$\mathrm{z}$ : beroeps-, bedrijfs- en respondentkenmerken

y: gemiddelde kwaliteit per set

Zoals gezegd kunnen de beroepen worden onderverdeeld in vakspecifieke beroepen en meer algemene beroepen. Bij algemene beroepen is de relatie tussen opleiding en beroep over het algemeen veel minder nauw dan bij vakspecifieke beroepen. We verwachten dan ook dat het effect van profielkenmerken, en dan met name het effect van opleiding, zal verschillen tussen algemene en vakspecifieke beroepen. Daarnaast zal het effect van de verschillende profielkenmerken bij vakspecifieke beroepen verschillen tussen bedrijfssectoren. In de Zorg zijn immers andere kennis en vaardigheden nodig dan in de IT. De verschillen tussen vakspecifieke beroepen binnen een bedrijfssector zullen naar verwachting minder groot zijn omdat daar over het algemeen de aard van de vereiste kennis en vaardigheden binnen sectoren minder verschilt dan tussen sectoren. Op basis van deze overwegingen zijn de beroepen in 5 groepen verdeeld namelijk vakspecifieke beroepen voor de IT, de Zorg en de Metaal, de leidinggevenden en de secretaresses. Voor elke groep zijn afzonderlijke vergelijkingen geschat. 
De opleidingskenmerken van de profielen zijn, zoals gezegd, deels afhankelijk van de gekozen beroepen. Een deel van de vooropleidingen is relevant voor het beroep en een deel niet. Om het effect van vooropleiding te meten maken we een onderscheid tussen opleidingsniveau en opleidingsrichting. Beide dimensies relateren we vervolgens aan de kenmerken van de functie. Het niveau van de vooropleiding kan exact overeenkomen met het niveau van de functie, het kan hoger zijn dan het niveau van de functie (overscholing) of het kan lager zijn (onderscholing). Bij de opleidingsrichting onderscheiden we eveneens drie categorieën: een vakspecifieke opleiding, een niet-vakspecifieke maar wel sectorspecifieke opleiding $^{3}$ en niet aansluitende opleidingen. De richting- en niveauvariabelen worden als dummy variabelen in het model opgenomen waarbij het exacte opleidingsniveau en de vakspecifieke opleiding als referentie worden genomen. Bij de leidinggevende beroepen is overigen nog een afzonderlijke dummy opgenomen voor management en bedrijfskundige opleidingen. Het idee daarbij is dat in leidinggevende functies zowel vak- of sectorspecifieke kennis als leidinggevende capaciteiten van belang zijn. We willen nagaan in hoeverre deze capaciteiten tijdens een opleiding kunnen worden verworven.

Werkervaring wordt eveneens aan beroepskenmerken gekoppeld. We onderscheiden daarbij drie soorten werkervaring; werkervaring in een gelijke functie, in een aanverwante functie en niet-relevante werkervaring. Voor relevante werkervaring is het verder interessant om na te gaan of er een verschillend effect is van langdurige en kortdurige ervaring. Sommige kennis en vaardigheden zullen tijdens een relatief korte inwerktijd kunnen worden opgedaan, andere vergen daarentegen een langdurige specialisatie. Te veel werkervaring in een beroep kan overigen ook een negatief signaal zijn als het bijvoorbeeld gaat om een starterfunctie. De persoon in kwestie is er dan blijkbaar niet in geslaagd om door te groeien naar een hogere functie. We nemen afzonderlijke dummy variabelen op voor kortdurige ervaring in een gelijke of aanverwante functie en langdurige werkervaring in een gelijke of aanverwante functie. De grens tussen kort- en langdurige ervaring wordt gelegd bij één jaar.

Bij werkloosheid maken we een onderscheid tussen kortdurige werkloosheid (minder dan een jaar) en langdurig werkloosheid (tussen één en vijf jaar). Deze grens van één jaar komt overeen met de grens die in POA wordt gehanteerd voor kortdurige werkloosheid. Voor de categorie huisvrouw/man maken we eenzelfde onderscheid tussen korte en lange duur.

3. Bij de vakspecifieke beroepen en leidinggevenden gaat het om opleidingen die niet exact aansluiten op het betreffende beroep maar wel op andere vakspecifieke beroepen in de sector. Voorbeelden van sectorspecifieke opleidingen zijn bijvoorbeeld HBO informatica voor de IT, MBO machinebankwerker voor de Metaal en MBO verpleegkunde voor de Zorg. Voor de functie van secretaresse worden andere administratieve opleidingen dan secretaresseopleidingen tot de sectorspecifieke opleidingen gerekend. Zie verder de bijlage. 


\section{De resultaten}

De resultaten van het rankorder model voor de voorkeursvolgorde en de logit voor de kans dat een kandidaat acceptabel wordt gevonden zijn te vinden in de bijlage. In deze paragraaf worden de belangrijkste resultaten met betrekking tot het belang van opleiding en werkervaring en met betrekking tot inactiviteit besproken en geï nterpreteerd. We bekijken hiertoe de voorkeurskansen die zijn berekend met behulp van vergelijking (3.4). Verder wordt in deze paragraaf ingegaan op het effect van arbeidsmarktknelpunten op de selectiecriteria.

Het effect van opleiding en werkervaring

Tabel 4.1 gaat in op het effect van opleiding voor vakspecifieke beroepen in de IT, de Zorg en de Metaal.

Tabel 4.1

De kans dat een kandidaat met een sectorspecifieke of geen specifieke opleiding wordt verkozen boven een kandidaat met een vakspecifieke opleiding

$\%$

IT

Sectorspecifieke opleiding

Geen specifieke opleiding

Zorg

Sectorspecifieke opleiding

Geen specifieke opleiding

Metaal

Sectorspecifieke opleiding

Geen specifieke opleiding

Leidinggevenden

Sectorspecifieke opleiding

Leidinggevende opleiding

Geen specifieke opleiding

Secretaresses

Sectorspecifieke opleiding

Tabel 4.2 geeft het effect van werkervaring. Zoals gezegd wordt er een onderscheid gemaakt tussen werkervaring in het zelfde beroep, werkervaring in een aanverwant beroep en geen relevante werkervaring. Bij de eerstgenoemde categorieën maken we verder onderscheid tussen korte werkervaring (minder dan een jaar) en lange werkervaring. Zoals verwacht hebben werkgevers in alle sectoren een sterke voorkeur voor kandidaten met ervaring in hetzelfde beroep. Dit effect is het grootst voor de leidinggevenden en voor de 
vakspecifieke beroepen in de IT. In beide gevallen is de kans dat werkgevers iemand met werkervaring in het zelfde beroep prefereren boven een kandidaat zonder relevante ervaring meer dan $80 \%$. Het verschil tussen lange en korte werkervaring is voor vrijwel alle beroepen verwaarloosbaar.

Het effect van werkervaring in een aanverwant beroep is veel kleiner dan het effect van ervaring in hetzelfde beroep. Gemiddeld ligt de kans dat iemand die ervaring heeft in een aanverwant beroep wordt verkozen boven iemand zonder relevante werkervaring tussen de $60 \%$ en $65 \%$. Alleen voor de vakspecifieke beroepen in de IT ligt deze kans wat hoger. Bij de leidinggevende beroepen is voor de aanverwante beroepen nog onderscheid gemaakt tussen ervaring in een leidinggevend beroep en ervaring in een sectorspecifiek beroep. Het blijkt dat voor ervaring in een leidinggevend beroep de duur van de ervaring belangrijker is dan voor ervaring die is opgedaan in een sectorspecifiek beroep. Blijkbaar kost het meer tijd om leidinggevende vaardigheden op te doen dan om (voor leidinggevenden) relevante vakspecifieke vaardigheden op te doen. Ten slotte is nog gekeken naar het effect van sectorspecifieke ervaring voor secretaresses. Het blijkt dat het belang van sectorspecifieke ervaring het grootst is voor secretaresses in de Zorg, maar ook in de andere bedrijfssectoren speelt het een rol.

Uit bovenstaande werd al duidelijk dat het effect van werkervaring in veel beroepen groter is dan het effect van opleiding. Om een idee te krijgen van de mate waarin werkervaring een substituut kan zijn voor opleiding hebben we de kans berekend dat iemand die niet de juiste opleiding heeft maar wel werkervaring wordt geprefereerd boven iemand met de juiste opleiding maar geen werkervaring. Tabel 4.3 geeft deze kans voor de verschillende beroepen.

De tabel laat zien dat voor de vakspecifieke beroepen de kans dat iemand die geen vakspecifieke opleiding heeft maar wel een sectorspecifieke opleiding en bovendien langer dan een jaar werkervaring in het betreffende beroep wordt verkozen boven iemand met een vakspecifieke opleiding zonder ervaring ongeveer $75 \%$ is. In de Zorg is deze kans veel lager namelijk $47 \%$. Het belang van ervaring is in de IT en de Metaal duidelijk groter dan het belang van opleiding. Werkervaring kan in deze sectoren een substituut zijn voor opleiding. In de Zorg is opleiding daarentegen juist relatief belangrijk. Werkervaring kan overigens vooral een substituut zijn voor kandidaten die weliswaar niet over een vakspecifieke opleiding beschikken maar wel een sectorspecifieke opleiding hebben. De tabel laat zien dat voor kandidaten die een opleiding hebben die in het geheel niet aansluit bij het beroep substitutie tussen opleiding en ervaring veel minder goed mogelijk is. In de Zorg is substitutie in dat geval zelfs vrijwel uitgesloten.

Bij de leidinggevende beroepen is substitutie tussen opleiding en werkervaring heel goed mogelijk. lemand die niet over een aansluitende opleidingsachtergrond beschikt maar wel ervaring heeft in hetzelfde beroep heeft een kans van $76 \%$ te worden verkozen boven iemand die wel een aansluitende opleiding heeft maar geen ervaring. Ook voor functie van secretaresse is deze kans hoog, namelijk $72 \%$. 
Tabel 4.2

De kans dat een kandidaat met relevante werkervaring in het zelfde of aanverwant beroep wordt verkozen boven een kandidaat zonder relevante werkervaring

IT

Kort werkervaring in aanverwant beroep

Lang werkervaring in aanverwant beroep

Kort werkervaring in zelfde beroep

Lang werkervaring in zelfde beroep

Zorg

Kort werkervaring in aanverwant beroep

Lang werkervaring in aanverwant beroep

Kort werkervaring in zelfde beroep

Lang werkervaring in zelfde beroep

Metaal

Kort werkervaring in aanverwant beroep

Lang werkervaring in aanverwant beroep

Kort werkervaring in zelfde beroep

Lang werkervaring in zelfde beroep

Leidinggevenden

Kort werkervaring in leidinggevend beroep

Lang werkervaring in leidinggevend beroep

Kort werkervaring in sectorspecifiek beroep

Lang werkervaring in sectorspecifiek beroep

Kort werkervaring in zelfde beroep

Lang werkervaring in zelfde beroep

Secretaresses

Kort werkervaring in aanverwant beroep

Lang werkervaring in aanverwant beroep

Kort werkervaring in zelfde beroep

Lang werkervaring in zelfde beroep

Werkervaring in IT

Werkervaring in Metaal

Werkervaring in Zorg 
Tabel 4.3

Substitutie tussen opleiding en werkervaring: de kans dat een kandidaat zonder vakspecifieke opleiding maar met werkervaring in het zelfde beroep wordt verkozen boven een kandidaat met een vakspecifieke opleiding zonder relevante werkervaring

$\%$

IT

Sectoropleiding en ervaring in zelfde beroep

76

Geen opleiding en ervaring in zelfde beroep

Zorg

Sectoropleiding en ervaring in zelfde beroep

Geen opleiding en ervaring in zelfde beroep

Metaal

Sectoropleiding en ervaring in zelfde beroep

Geen opleiding en ervaring in zelfde beroep

Leidinggevenden

Sectoropleiding en ervaring in zelfde beroep

Management opleiding en ervaring in zelfde beroep

Geen opleiding en ervaring in zelfde beroep

Secretaresses

Sectoropleiding en ervaring in zelfde beroep

\section{Werklozen en herintreders}

In welke mate concurreren kandidaten zonder baan met kandidaten die al een baan hebben, en is daarin een verschil tussen iemand die werkloos is en iemand die huisvrouw of -man is? Uit tabel 4.4 blijkt dat voor de vakspecifieke beroepen, kortdurige werkloosheid er niet zoveel toe doet.Langdurige werkloosheid verkleint de kans dat iemand wordt gekozen wel aanzienlijk. Gemiddeld is de kans dat iemand die langdurig werkloos is wordt verkozen boven iemand met een baan 35\%. In de Zorg is deze kans wat groter en in de IT wat lager maar de verschillen tussen bedrijfssectoren zijn minimaal. Voor de leidinggevende beroepen doet kortdurige werkloosheid er wel toe. lemand die kort werkloos is heeft slechts een kans van $37 \%$ te worden verkozen boven iemand met een baan. Voor langdurige werklozen is deze kans nog lager namelijk $26 \%$. Blijkbaar is het negatieve signaal dat werkloosheid afgeeft veel sterker voor leidinggevende beroepen dan voor vakspecifieke beroepen, want technische en economische scholingsveroudering zal voor leidinggevenden juist minder een rol spelen dan voor vakspecifieke beroepen. Opvallend is dat bij de secretaresses alleen kortdurige werkloosheid de kans om gekozen te worden verkleint en langdurige werkloosheid geen effect heeft. 
Voor zover werkloosheid alleen een indicatie is van mogelijke scholingsveroudering mag verwacht worden dat er weinig verschil is tussen werklozen en kandidaten die huisvrouw/man zijn geweest. Werkloze kandidaten hebben mogelijk iets meer binding met de arbeidsmarkt en vanuit het perspectief van scholingsveroudering zal er wellicht een lichte voorkeur voor werklozen boven huisvrouwen of -mannen bestaan. Langdurige werkloosheid heeft echter ook een signaalfunctie. lemand die er gedurende lange tijd niet in slaagt om een baan te vinden beschikt blijkbaar niet over de juiste kennis en vaardigheden. Dit signaaleffect zal overigens afhangen van de arbeidsmarktsituatie. In tijden van hoogconjunctuur is de signaalfunctie sterker dan in tijden van laagconjunctuur (zie ook $\mathrm{G}$. Russo, 1996).

Tabel 4.4

De kans dat een kandidaat die werkloos of huisvrouw/man is wordt verkozen boven een kandidaat met werk

\begin{tabular}{|c|c|c|c|c|c|}
\hline & \multicolumn{3}{|c|}{ Vakspecifieke beroepen } & \multicolumn{2}{|c|}{ Algemene beroepen } \\
\hline & IT & Zorg & Metaal & Leidinggevenden & Secretaresses \\
\hline Kort werkloos & 43 & 54 & 49 & 37 & 25 \\
\hline Lang werkloos & 32 & 38 & 35 & 26 & 46 \\
\hline Kort huisvrouw/man & 28 & 41 & 44 & 39 & 63 \\
\hline Lang huisvrouw/man & 36 & 48 & 36 & 46 & 51 \\
\hline
\end{tabular}

Tabel 4.4 laat zien dat in de IT kandidaten die korte tijd huisvrouw of -man zijn geweest een kleinere kans hebben om te worden verkozen dan kandidaten de korte tijd werkloos zijn geweest. Kandidaten die lange tijd huisvrouw zijn geweest hebben echter geen lagere kans om gekozen te worden dan kandidaten die lang werkloos zijn geweest. In de zorgsector hebben kandidaten die lange tijd huisvrouw zijn geweest juist de voorkeur boven kandidaten die lang werkloos zijn geweest. Daar in deze sector veel vrouwen werken, die vaak voor lange tijd stoppen met werken om voor de kinderen te zorgen en weer aan de slag willen als de kinderen wat groter zijn, is men hier waarschijnlijk veel meer gewend te werken met herintreders. Bovendien speelt scholingsveroudering minder een rol in deze sector, zodat herintreders relatief makkelijk weer aan de slag kunnen. In de Metaal is er geen verschil tussen herintreders en werklozen. Bij de leidinggevende beroepen hebben werkgevers eveneens een voorkeur voor herintreders boven langdurig werklozen. Voor het beroep secretaresses worden de kansen op een baan tenslotte nauwelijks beï nvloedt door tijdelijke of langdurige terugtrekking van de arbeidsmarkt.

\section{Schoolverlaters}

Schoolverlaters met een goed aansluitende opleiding hebben voor geen van de beroepen een kleinere kans om te worden gekozen dan kandidaten met een baan voor zover die geen relevante ervaring hebben. Uit tabel 4.5 blijkt dat de voorkeur voor werkenden dus uitsluitend geldt voor kandidaten die in het betreffende beroep of een aanverwant beroep werkervaring hebben opgedaan. Verder blijkt eveneens dat werkgevers de voorkeur geven aan kandidaten die kort werkloos zijn, maar wel relevante ervaring hebben opgedaan, boven 
schoolverlaters. Voor langdurig werklozen geldt dit echter in de meeste beroepen niet. Tenslotte prefereren werkgevers ook herintreders met langdurige ervaring boven schoolverlaters.

Tabel 4.5

De kans dat werkgevers een schoolverlater met een vakspecifieke opleiding verkiezen boven andere kandidaten

Vakspecifieke beroepen
IT $\quad$ Zorg $\quad$ Metaal
Leidinggemenden Seroepen

\begin{tabular}{cccccc}
$\begin{array}{c}\text { Aansluitende opleiding en } \\
\text { geen ervaring in beroep }\end{array}$ & 50 & 57 & 51 & 48 & 64 \\
$\begin{array}{c}\text { Aansluitende opleiding en } \\
\text { wel ervaring in beroep } \\
\text { Kort werkloos, aansluitende } \\
\text { opleiding en wel ervaring } \\
\text { in beroep }\end{array}$ & 19 & 32 & 27 & 14 & 37 \\
$\begin{array}{c}\text { Lang werkloos, aansluitende } \\
\text { opleiding en wel ervaring } \\
\text { in beroep }\end{array}$ & 23 & 28 & 28 & 22 & 64 \\
$\begin{array}{c}\text { Lang huisvrouw, aansluiten- } \\
\text { de opleiding en wel erva- } \\
\text { ring in beroep }\end{array}$ & 47 & 46 & 55 & 33 & 41 \\
\hline
\end{tabular}

Als werkgevers moeten kiezen tussen een schoolverlater die geen vakspecifieke opleiding heeft maar wel een aanverwante sectorspecifieke opleiding en andere categorieën arbeid hebben ze vrijwel altijd de voorkeur voor andere categorieën. Alleen voor het beroep secretaresse hebben werkgevers liever een schoolverlater met een administratieve opleiding dan een werkende kandidaat met de juiste opleiding die geen relevante werkervaring heeft.

Tabel 4.6

De kans dat werkgevers een schoolverlater met een sectorspecifieke opleiding verkiezen boven andere kandidaten

\begin{tabular}{lll} 
Vakspecifieke beroepen & \multicolumn{2}{c}{ Algemene beroepen } \\
IT & Zorg $\quad$ Metaal Leidinggevenden Secretaresses
\end{tabular}

\begin{tabular}{cccccc}
$\begin{array}{c}\text { Aansluitende opleiding en } \\
\text { geen ervaring in beroep }\end{array}$ & 43 & 29 & 48 & 44 & 57 \\
$\begin{array}{c}\text { Aansluitende opleiding en } \\
\text { wel ervaring in beroep }\end{array}$ & 15 & 13 & 25 & 12 & 30 \\
$\begin{array}{c}\text { Kort werkloos, aansluitende } \\
\text { opleiding en wel ervaring } \\
\text { in beroep }\end{array}$ & 18 & 11 & 26 & 19 & 57 \\
$\begin{array}{c}\text { Lang werkloos, aansluitende } \\
\text { opleiding en wel ervaring } \\
\text { in beroep }\end{array}$ & 27 & 19 & 38 & 29 & 34 \\
$\begin{array}{c}\text { Lang huisvrouw, aansluiten- } \\
\text { de opleiding en wel } \\
\text { ervaring in beroep }\end{array}$ & 24 & 14 & 37 & 14 & 29 \\
\hline
\end{tabular}


Bovenstaande resultaten moeten wel met de nodige voorzichtigheid worden geï nterpreteerd. $E r$ is namelijk geen rekening gehouden met mogelijke interactie tussen het effect van werkervaring en het effect van inactiviteit. Het is bijvoorbeeld denkbaar dat voor langdurig inactieven het effect van werkervaring kleiner is dan voor kandidaten die werkzaam zijn. $\mathrm{Er}$ zijn echter te weinig waarnemingen om met deze interactie-effecten rekening te houden. Verder geldt dat er een maximum gesteld is aan de periode van inactiviteit.Waarschijnlijk is de situatie voor kandidaten die langer dan 5 jaar inactief zijn geweest veel minder rooskleurig.

Verder is geen rekening gehouden met de leeftijd van de kandidaat. Er is dus verondersteld dat de schoolverlater even oud is als de andere kandidaten. In de praktijk zal een herintreder die al enige werkervaring heeft opgedaan veel ouder zijn dan een schoolverlater. Het blijkt dat in de zorgsector de kansen voor oudere kandidaten afnemen maar in de Metaal en de IT de kansen voor oudere kandidaten juist wat toenemen, maar alleen voor de Metaal zijn de verschillen significant.

\section{Knelpunten en selectiecriteria}

In het bovenstaande werd ingegaan op de voorkeuren van werkgevers. Zoals gezegd bepalen de voorkeuren voor een belangrijk deel of een kandidaat acceptabel is voor een functie. Echter, werkgevers kunnen wel sterk de voorkeur hebben voor kandidaten met een aansluitende opleiding en vijf jaar werkervaring maar wat doen ze als deze kandidaten niet voorhanden zijn? Op basis van de schattingsresultaten krijgen we enigszins inzicht in de invloed van de arbeidsmarktsituatie op de selectiecriteria die werkgevers hanteren. We bekijken hiertoe het effect van knelpunten in de personeelsvoorziening en het effect van de gemiddelde kwaliteit van de kandidaten waaruit men kan kiezen op de kans dat een kandidaat acceptabel is. Tabel 4.7 geeft de richting van deze effecten voor de verschillende beroepen. Een positief effect van knelpunten betekent dat een willekeurige kandidaat eerder acceptabel wordt gevonden naarmate er door het bedrijf meer knelpunten in de personeelsvoorziening worden ondervonden. Bedrijven gaan in dat geval minder streng selecteren als er sprake is van knelpunten op de arbeidsmarkt. Het blijkt dat werkgevers in de IT en de Metaal minder streng selecteren als ze moeilijkheden hebben om vacatures te vervullen. In de Zorg wordt geen significant effect gevonden van knelpunten. Voor de leidinggevende beroepen wordt echter een negatief effect van knelpunten gevonden. Dit resultaat plaatst enkele vraagtekens bij de causaliteit van het verband. Mogelijk ondervinden sommige bedrijven juist meer knelpunten bij het invullen van vacatures voor leidinggevenden omdat ze strenger selecteren dan andere bedrijven. Het effect voor secretaresses is wel weer positief. Bedrijven die moeilijkheden hebben om vacatures voor secretaresses te vervullen gaan minder streng selecteren.

Als het effect van de kwaliteit van het aanbod negatief is, dan is de kans dat een kandidaat acceptabel wordt gevonden groter naarmate de gemiddelde kwaliteit van alle kandidaten waaruit de werkgever kan kiezen lager is. Een lagere kwaliteit van het arbeidsaanbod leidt dan tot minder strenge selectiecriteria. Het blijkt dat in de IT en de Metaal het effect inderdaad negatief is. Voor de secretaresses geldt dat eveneens. Opvallend is dat in de Zorg juist een omgekeerd effect wordt gevonden. Naarmate de gemiddelde kwaliteit in een 
set beter is neemt de kans dat een kandidaat acceptabel wordt gevonden juist toe. Geconcludeerd kan worden dat knelpunten in de zorgsector met name tot openstaande vacatures leiden terwijl in de Metaal en de IT eerder minder geschikte kandidaten worden aangenomen. Opvallend is wel dat deze uitkomsten niet overeenkomen met de uitkomsten van de enquête. In de Zorg zegt namelijk $32 \%$ van de respondenten de selectiecriteria aan te passen als een vacature niet vervuld wordt terwijl dit in de IT en de Metaal respectievelijk $21 \%$ en $23 \%$ is. Dit heeft er mogelijk mee te maken dat de selectiecriteria in de IT en Metaal sowieso al veel minder streng zijn. Er wordt in deze sectoren meer op knelpunten geanticipeerd dan in de Zorg. Achteraf valt er dan ook minder aan te passen.

Tabel 4.7

De invloed van knelpunten in de personeelsvoorziening en de kwaliteit van het arbeidsaanbod op de selectiecriteria

$\begin{array}{lll}\text { Vakspecifieke beroepen } & \text { Algemene beroepen } \\ \text { IT } & \text { Zorg } \quad \text { Metaal Leidinggevenden Secretaresses }\end{array}$

$\begin{array}{lccccc}\text { Knelpunten } & + & 0 & + & - & + \\ \text { Kwaliteit arbeidsaanbod } & - & + & - & 0 & -\end{array}$

\section{Betekenis voor het project Onderwijs-Arbeidsmarkt}

Impliciete veronderstelling over voorkeuren in het POA-model

Aan het POA-model liggen een aantal veronderstellingen ten grondslag met betrekking tot voorkeuren van werkgevers die verstrekkende gevolgen hebben. Bij het bepalen van het arbeidsmarktperspectief voor opleidingen wordt verondersteld dat schoolverlaters alleen concurreren met kortdurige werklozen. Langdurig werklozen en niet-participerenden worden niet als concurrenten van schoolverlaters beschouwd en derhalve buiten beschouwing gelaten. Op basis van dit onderzoek kunnen deze veronderstellingen met betrekking tot voorkeuren expliciet getest worden. In de vorige paragraaf bleek dat in verschillende beroepen langdurig werklozen en herintreders met veel relevante werkervaring wel degelijk de voorkeur hebben boven schoolverlaters. Dat geldt met name als het gaat om schoolverlaters die niet over de juiste opleidingachtergrond beschikken. Geconfronteerd met tekorten bij een bepaalde opleiding rekruteren werkgevers dus vaak liever herintreders dan schoolverlaters van andere (aanverwante) opleidingen.

Een andere veronderstelling in het POA-model is dat werkenden die hun baan verliezen eveneens geen concurrenten zijn voor schoolverlaters zodat een negatieve uitbreidingvraag het perspectief van schoolverlaters niet verslechtert. Deze veronderstelling gaat alleen op voor werkenden die buiten hun eigen domein werkzaam waren en dus nauwelijks relevante ervaring hebben. Als werkgevers moeten kiezen tussen schoolverlaters en werkenden met enige relevante ervaring gaat hun voorkeur uit naar de laatsten. 
Geconcludeerd kan worden dat bij verdere ontwikkelingen van de POA-methodiek meer rekening moet worden gehouden met de voorkeuren van werkgevers met betrekking tot verschillende aanbodcategorieën. Vooral uit het oogpunt van de prognoses van knelpunten in de personeelsvoorziening voor werkgevers en van de arbeidsmarktperspectieven voor schoolverlaters is het van belang dat ook andere arbeidsaanbodcategorieën in kaart worden gebracht. De Grip e.a (1999) hebben weliswaar reeds de inzet van niet-direct inzetbaar arbeidsaanbod bij knelpunten op de arbeidsmarkt geanalyseerd maar moeten hierbij nog een aantal sterke aannames maken omtrent het voorkeursgedrag van werkgevers. In het vervolg van deze paragraaf zal worden nagegaan hoe de indicator voor toekomstige knelpunten naar beroep kan worden verbeterd door rekening te houden met alternatieve aanbodcategorieën.

\section{Knelpuntenindicator naar beroep}

Het ROA heeft een knelpuntenindicator per beroepsgroep ontwikkeld waarbij de vraag naar verschillende opleidingen vanuit een beroep wordt gerelateerd aan het aanbod per opleiding. Deze indicator toekomstige arbeidsmarktperspectieven per beroepsgroep wordt als volgt gedefinieerd:

$$
\begin{aligned}
& I T K B_{j}=\frac{\sum_{i} p_{i} x_{i j t}}{\sum_{i} x_{i j t}} \\
& p_{i}=\frac{y_{i t}}{\sum_{j} x_{i j t}} \quad \text { als } \quad y_{i t} \leq \sum_{j} x_{i j t} \\
& p_{i}=1 \quad \text { als } \quad y_{i t}>\sum_{j} x_{i j t}
\end{aligned}
$$

waar $x_{\mathrm{ijt}}$ de totale vraag naar personen met opleiding $i$ vanuit beroep $j$ op tijdstip $t$

$y_{\mathrm{ijt}} \quad$ het totale aanbod personen met opleiding $i$ op tijdstip $t$

$\mathrm{p}_{\mathrm{i}} \quad$ de kans dat een werkgever iemand met opleiding $i$ aan kan trekken.

Tot het arbeidsaanbod worden gerekend de werkenden op tijdstip $t-1$ gecorrigeerd voor de arbeidsmarktuitstroom tussen tijdstip $t-1$ en tijdstip $t$, de arbeidsmarktinstroom van schoolverlaters en de kortdurige werkloosheid op tijdstip $t$-1:

$$
y_{t i}=\sum_{j} x_{i j t-1}+w / h_{i t-1}+i n s t r_{i t-1}-v v_{i t-1}
$$

waar $\quad$ wlh $_{\mathrm{it}-1}$ de kortdurige werkloosheid voor opleiding $i$ op tijdstip $t-1$

instr $_{\text {it }}$ de arbeidsmarktinstroom van schoolverlaters met opleiding $i$ tussen $t-1$ en $t$ $\mathrm{v}_{\mathrm{it}}$ de vervangingsvraag voor opleiding $i$ tussen $t-1$ en $t$ 
Langdurig werklozen en niet-participerenden worden niet tot het arbeidsaanbod gerekend. Op basis van de resultaten uit de vorige paragraaf kan worden geconcludeerd dat de indicator kan worden verbeterd door het aanbod van deze categorieën wel mee te nemen. Hierbij spelen twee problemen. In de eerste plaats zal maar een klein deel van de nietparticiperenden zich op de arbeidsmarkt willen gaan aanbieden. Tabel 5.1 geeft per opleidingssector het totale percentage niet-participerenden en het percentage nietparticiperenden dat op kort termijn beschikbaar is voor de arbeidsmarkt. De tabel laat zien dat er een aanzienlijke reserve is aan arbeidskrachten, met name op lager en middelbaar niveau. Het percentage dat op korte termijn beschikbaar is, is echter erg laag. Uit achterliggende informatie blijkt dat met name personen die ouder zijn dan 45 jaar nauwelijks beschikbaar zijn. Personen jonger dan 45 jaar zijn vaker beschikbaar maar de reserve van niet-partciperenden jonger dan 45 jaar is erg klein. Onbeschikbaar op korte termijn betekent vanzelfsprekend niet dat deze groep in zijn geheel verloren is voor de arbeidsmarkt. Het betekent echter wel dat er flink wat moeite moet worden gedaan om deze groep terug te laten keren naar de arbeidsmarkt. Om een duidelijker beeld te krijgen van de bereidheid om toe te treden tot de arbeidsmarkt is verder onderzoek naar keuzegedrag van nietparticiperenden noodzakelijk.

Tabel 5.1

Het aandeel van niet-particperenden per opleidingssector, 1999

Totaal niet-particperend

$\%$
Niet participerend maar beschikbaar

$\%$

Basisonderwijs
VMBO theorie
VMBO landbouw en techniek
VMBO economie
VMBO verzorging
HAVO / VWO
MBO landbouw en techniek
MBO economie
MBO dienstverlening en gezondheidszorg
HBO landbouw en techniek
HBO economie
HBO onderwijs en sociaal-cultureel
HBO paramedisch
WO landbouw en techniek
WO economie
WO letteren en sociaal-cultureel
WO medisch

$\begin{array}{rl}54 & 5 \\ 39 & 4 \\ 14 & 2 \\ 39 & 5 \\ 62 & 5 \\ 24 & 4 \\ 12 & 3 \\ 22 & 1 \\ 30 & 2 \\ 11 & 3 \\ 9 & 3 \\ 22 & 1 \\ 13 & 1 \\ 6 & 2 \\ 7 & 1 \\ 11 & 1 \\ 5 & 0 \\ & 2 \\ & \\ 13 & 0\end{array}$

\section{Bron: ROA/CBS}

Een tweede probleempunt is dat langdurig werklozen en herintreders alleen met schoolverlaters concurreren als ze in het verleden relevante werkervaring hebben opgedaan. In de EBB is echter maar beperkte informatie over het arbeidsverleden opgenomen. In het Sociaal Economisch Panel is wel informatie opgenomen over de vorige werkkring. Tabel 5.2 geeft het percentage van de niet-participerenden dat in het verleden betaald werk heeft gehad. 
Uit de tabel blijkt dat rond de $90 \%$ van de inactieven in het verleden een betaalde werkkring heeft gehad. Alleen voor personen met slechts basisonderwijs is dit percentage een stuk lager. Voor de inzet van dit arbeidsaanbod is het echter vooral van belang wat voor soort werk dit betrof, daar werkgevers alleen herintreders in dienst willen nemen als ze over voor de functie relevante werkervaring beschikken. In welke mate het arbeidsaanbod van herintreders beschikt over relevante werkervaring voor de verschillende functie zou daarom nader onderzocht moeten worden.

Gezien de genoemde problemen bij het bepalen van het aanbod van inactieven en langdurig werklozen is het vooralsnog niet goed mogelijk om bij het bepalen van de knelpunten per beroepsgroep rekening te houden met het additionele aanbod. Verder onderzoek naar het arbeidsaanbod per beroepsgroep is noodzakelijk. Het gaat daarbij enerzijds om de werkervaring die men in het verleden heeft opgedaan en anderzijds om de mate waarin nietparticiperenden zich daadwerkelijk op de arbeidsmarkt zouden willen aanbieden.

Tabel 5.2

Percentage niet-participerenden dat in het verleden betaald werk heeft gehad, 1998

$\begin{array}{ll}\text { Basisonderwijs } & 83 \\ \text { VMBO } & 87 \\ \text { MBO, HAVO/VWO } & 94 \\ \text { HBO } & 92 \\ \text { WO } & 93 \\ \text { Totaal } & 89\end{array}$

Bron: SEP

\section{Conclusies}

In dit werkdocument is getracht om meer inzicht te krijgen in de voorkeuren van werkgevers met betrekking tot verschillende soorten arbeid. Het blijkt dat werkgevers vooral veel belang hechten aan relevante werkervaring, d.w.z. werkervaring in een zelfde functie als waarvoor wordt gesolliciteerd. Relevante werkervaring is vaak belangrijker dan de juiste opleiding, met name voor veel functies in de IT en de Metaal. Voor functies in de Zorg is het wel heel belangrijk om over de juiste opleiding te beschikken, maar ook in deze sector speelt relevante werkervaring een grote rol in de selectieprocedure. Overigens lijkt de duur van de werkervaring er niet zo veel toe te doen. Kandidaten met ervaring korter dan een jaar zijn even geliefd als kandidaten die langer ervaring hebben. Blijkbaar kunnen de belangrijkste kennis en vaardigheden voor een functie vaak in een relatief korte periode worden opgedaan.

Kandidaten die werkloos zijn of inactief hebben een kleinere kans om te worden gekozen dan kandidaten die een baan hebben. Over het algemeen geldt dat langdurige werklozen of inactieven een kleinere kans hebben dan kortdurig werklozen en inactieven. Het effect van werkloosheid en inactiviteit verschilt echter tussen bedrijfssectoren en beroepen. In de Zorg hebben herintreders bijvoorbeeld een grotere kans om te worden gekozen dan in de overige sectoren. Werkgevers hebben een voorkeur voor schoolverlaters boven kandidaten die 
werkzaam zijn in een ander beroep dan waarvoor gesolliciteerd wordt. Als werkgevers moeten kiezen tussen een schoolverlater en iemand die werkloos is of inactief maar over veel (relevante) ervaring beschikt, dan kiezen ze vaak voor de laatste.

Uit het onderzoek blijkt verder dat de selectiecriteria worden aangepast onder de druk van arbeidsmarktomstandigheden. Dat geldt met name voor de IT en de Metaal. Dit betekent dat tekorten niet direct tot openstaande vacatures leiden maar dat in eerste instantie personeel wordt geworven dat niet over alle vereiste kwalificaties beschikt.

De resultaten van het onderzoek zijn van groot belang voor de methodiek van het project Onderwijs-Arbeidsmarkt. Tot nu toe werden veel veronderstellingen gemaakt over het voorkeursgedrag van werkgevers die niet empirisch konden worden getoetst. Op basis van dit onderzoek blijkt dat de voorkeuren van werkgevers soms anders liggen dan verondersteld. Dit heeft met name consequenties voor de knelpuntindicatoren naar opleiding en beroep (ITKP en ITKB) en de indicator voor toekomstige arbeidsmarktperspectieven (ITA). Deze indicatoren kunnen worden verbeterd door ook rekening te houden met het aanbod van herintreders. Hiervoor is echter wel aanvullend onderzoek nodig naar zowel het aanbodgedrag als het arbeidsverleden van niet-participerenden.

Tenslotte is van belang om nog eens op te merken dat het onderzoek slechts betrekking had op een drietal sectoren. Het is de vraag in welke mate de resultaten ook opgaan voor andere bedrijfssectoren. Het feit dat veel resultaten niet zo verschillen tussen drie onderling sterk verschillende sectoren biedt wat dat betreft enige geruststelling. Een ander punt is dat het aantal bedrijven dat is geï nterviewd relatief gering is waardoor het nauwelijks mogelijk is om interactie-effecten te meten. Het is bijvoorbeeld mogelijk dat het effect van relevante werkervaring op werkgeversvoorkeuren verschilt tussen werkenden, werklozen en inactieven. Tenslotte was het in deze opzet niet goed mogelijk om meer duidelijkheid over substitutiemogelijkheden tussen opleidingen te verkrijgen. Het wordt bijvoorbeeld wel duidelijk dat hierin, zoals verwacht, verschillen zijn tussen beroepen en sectoren maar door het gering aantal waarnemingen is het niet mogelijk om uitspraken te doen op een laag aggregatieniveau. Om deze vragen te beantwoorden zou soortgelijk onderzoek op grotere schaal moeten plaatsvinden.

\section{Literatuur}

Beek, K.W.H. van, C.C. Koopman, B.M.S. van Praag (1997), Shopping at the labour market: A real tale of fiction, European Economic Review, Vol. 41, pp. 295-317.

Borghans, L., W. Smits, J.D. Vlasblom (2000), Employers' preferences with respect to apprenticeship: a vignette survey, paper presented at ESPE 2000.

Grip, A. de, A. Jacobs en J.D. Vlasblom (1999), De inzet van niet-direct inzetbaar arbeidsaanbod bij knelpunten op de arbeidsmarkt, ROA-W-1999/2, Maastricht.

ROA (1999), De arbeidsmarkt naar opleiding en beroep tot 2004, ROA-R-1999/8, Maastricht.

ROA (1999), De arbeidsmarkt naar opleiding en beroep tot 2004, Statistische Bijlage, ROA-R1999/8B. 
Russo, G. (1996), Firm's recruitment behaviour: on empirical investigation of the use of search channels, the rate of arrival of applicants, and the spatial radius of search, Amsterdam: Thesis Publishers.

Smits, W., J. Delmee (1998), De arbeidsmarkt voor informatici, ROA-R-1998/2, Maastricht.

Wolf, I. de, R. van der Velden (1999), The influence of educational characteristics in selection processes for academic jobs: an experiment among employers, Rijksuniversiteit Utrecht. 


\section{Bijlage A: Schattingsresultaten}

Tabel A.1

Rank-order model: schattingsresultaten vakspecifieke beroepen IT

Coefficiënt Standaard fout

p-waarde

Persoonskenmerken:

Leeftijd

Leeftijd kwadraat /100

0,02

0,05

0,33

Man

Hobby muziek

$-0,05$

0,07

0,21

$-0,16$

0,12

0,10

Hobby vertegenwoordigend / leidinggevend

0,05

0,24

0,41

0,11

0,21

0,02

0,17

Hobby computers

0,25

0,17

0,30

0,46

Opleidingskenmerken:

Sectorspecifieke opleiding

$-0,29$

$-0,95$

0,17

0,12

0,07

Overschoold

Onderschoold

0,08

0,18

0,05

$-0,04$

0,13

0,00

Opleiding via leerlingwezen

0,05

0,23

0,32

0,36

Kenmerken werkervaring:

Werkervaring in aanverwant beroep $(<1$ jaar $)$

Werkervaring in aanverwant beroep ( $>1$ jaar)

0,45

0,23

0,41

Werkervaring in zelfde beroep $(<1$ jaar $)$

Werkervaring in zelfde beroep ( $>1$ jaar)

0,93

1,42

0,18

0,02

1,46

0,40

0,00

0,14

Kenmerken inactiviteit:

Werkloos $(<1$ jaar)

$-0,27$

$-0,77$

0,76

0,36

Werkloos ( $>1$ jaar)

$-0,94$

0,29

$-0,58$

Huisvrouw/man ( $>1$ jaar)

Student/scholier studeert binnenkort af

$-0,00$

0,27

0,20

0,00

0,00

0,00

Mean log-likelihood $\quad-25,39$ 
Tabel A.2

Logit model kans op acceptabel: schattingsresultaten vakspecifieke beroepen IT

Coefficiënt Standaard fout

p-waarde

Constante

$-2,11$

2,04

0,15

Persoonskenmerken:

Leeftijd

0,00

$-0,04$

0,09

0,12

0,19

Man

0,04

0,37

0,36

0,18

Hobby Vertegenwoordigend / Leidinggevend

$-0,05$

Hobby Computers

0,07

0,29

0,48

0,39

0,42

0,38

0,31

0,43

0,40

Opleidingskenmerken:

Sectorspecifieke opleiding

$-1,02$

0,31

0,00

Geen beroeps- of sectorspecifieke opleiding

$-1,62$

0,24

0,00

Overschoold

0,27

0,19

$-0,20$

0,25

0,21

Opleiding via leerlingwezen

0,34

0,37

0,18

Kenmerken werkervaring:

Werkervaring in aanverwant beroep $(<1$ jaar $)$

1,48

1,81

0,45

0,00

Werkervaring in aanverwant beroep ( $>1$ jaar)

2,75

0,24

0,00

Werkervaring in zelfde beroep $(<1$ jaar $)$

3,10

0,56

0,00

Werkervaring in zelfde beroep ( $>1$ jaar)

0,32

0,00

Kenmerken inactiviteit:

Werkloos $(<1$ jaar $)$

$-0,52$

0,66

0,22

$-0,61$

$-1,45$

0,44

0,08

Huisvrouw/man $(<1$ jaar $)$

$-0,99$

0,55

0,00

Huisvrouw/man ( $>1$ jaar)

0,49

0,30

0,00

Student/scholier studeert binnenkort af

0,38

0,10

Functies:

Helpdeskmedewerker

0,24

0,44

0,30

$-0,13$

0,31

0,33

Projectadviseur

$-0,20$

0,32

0,26

Kenmerken bedrijfsomvang:

$<10$ werknemers

10-99 werknemers

$-2,55$

$-0,58$

0,49

0,26

0,00

Ontwikkeling bedrijf:

Afgelopen 12 maanden gegroeid

0,69

0,25

0,00

Kenmerken vacatures:

Moeilijk om vacatures op te vullen

0,51

0,26

0,03

Geslacht respondent

0,93

0,34

0,00

Respondent is directeur/eigenaar

0,89

0,33

0,00

Respondent is personeelsfunctionaris

0,70

0,27

0,00

Andere kenmerken:

Gemiddeld kwaliteit set

$-0,27$

0,13

0,02

Mean log-likelihood $\quad-0,51$ 
Tabel A.3

Rank-order model: schattingsresultaten vakspecifieke beroepen Zorg

Coefficiënt Standaard fout $\quad$-waarde

Persoonskenmerken:

Leeftijd

Leeftijd kwadraat /100

Man

Hobby muziek

Hobby vertegenwoordigend / leidinggevend

Hobby sport

Hobby computers

$-0,05$

0,07

0,00

$-0,10$

$-0,18$

$-0,14$

$-0,09$

Opleidingskenmerken:

Sectorspecifieke opleiding

Geen beroeps- of sectorspecifieke opleiding

Overschoold

Onderschoold

Opleiding via leerlingwezen

Kenmerken werkervaring:

Werkervaring in aanverwant beroep $(<1$ jaar $)$

Werkervaring in aanverwant beroep ( $>1$ jaar)

Werkervaring in zelfde beroep $(<1$ jaar $)$

Werkervaring in zelfde beroep ( $>1$ jaar)

Kenmerken inactiviteit:

Werkloos $(<1$ jaar $)$

Werkloos (> 1 jaar)

Huisvrouw/man $(<1$ jaar $)$

Huisvrouw/man ( $>1$ jaar)

Student/scholier studeert binnenkort af

Mean log-likelihood $\quad-25,13$

$\begin{array}{rrr}-1,14 & 0,12 & 0,00 \\ -2,04 & 0,15 & 0,00 \\ 0,11 & 0,13 & 0,19 \\ 0,04 & 0,18 & 0,42 \\ 0,14 & 0,10 & 0,10\end{array}$

$\begin{array}{lll}0,58 & 0,27 & 0,02\end{array}$

$0,67 \quad 0,12 \quad 0,00$

$\begin{array}{lll}1,15 & 0,19 & 0,00\end{array}$

$\begin{array}{lll}1,03 & 0,10 & 0,00\end{array}$

$\begin{array}{lll}0,18 & 0,33 & 0,29\end{array}$

$\begin{array}{lll}-0,48 & 0,17 & 0,00\end{array}$

$\begin{array}{lll}-0,35 & 0,30 & 0,12\end{array}$

$\begin{array}{lll}-0,10 & 0,11 & 0,18\end{array}$

$\begin{array}{rrr}-0,10 & 0,11 & 0,18 \\ 0,27 & 0,23 & 0,12\end{array}$
0,19

0,50

0,30

0,13

0,31

00

42

10

2

00

29

8


Tabel A.4

Logit model kans op acceptabel: schattingsresultaten vakspecifieke beroepen Zorg

Coefficiënt Standaard fout p-waarde

Constante

$-1,28$

1,91

0,25

Persoonskenmerken:

Leeftijd

$-0,16$

0,10

0,15

0,06

Leeftijd kwadraat /100

0,22

0,16

Hobby muziek

$-0,12$

0,37

0,07

Hobby vertegenwoordigend / leidinggevend

$-0,69$

0,36

0,23

Hobby sport

Hobby computers

$-0,46$

0,33

0,09

$-0,45$

0,37

0,11

Opleidingskenmerken:

Sectorspecifieke opleiding

$-2,32$

$-3,79$

0,27

0,33

0,00

0,47

0,24

0,00

Overschoold

$-0,28$

0,30

0,02

Onderschoold

0,52

0,18

0,18

Opleiding via leerlingwezen

0,56

0,41

0,24

0,48

0,00

Kenmerken werkervaring:

Werkervaring in aanverwant beroep $(<1$ jaar)

Werkervaring in aanverwant beroep ( $>1$ jaar)

Werkervaring in zelfde beroep $(<1$ jaar)

Werkervaring in zelfde beroep ( $>1$ jaar)

0,25

0,09

1,97

0,00

0,00

Kenmerken inactiviteit:

Werkloos ( $<1$ jaar)

$-0,11$

$-0,21$

0,02

0,70

0,44

Werkloos $(>1$ jaar)

$-0,69$

Huisvrouw/man ( $>1$ jaar)

$-0,69$

0,31

0,57

0,25

0,49

0,26

0,00

Student/scholier studeert binnenkort af

0,39

0,38

Functies:

Helpende

Zieken- of Bejaardenverzorgende

Medisch analist

$-0,74$

0,39

0,03

$-0,11$

0,36

0,38

0,59

0,43

0,09

Activiteitenbegeleider

0,45

0,28

0,05

Kenmerken bedrijfsomvang:

10-99 werknemers

0,87

0,21

0,00

Ontwikkeling bedrijf:

Afgelopen 12 maanden gegroeid

$-0,13$

0,17

0,22

Kenmerken vacatures:

Moeilijk om vacatures op te vullen

0,19

0,46

Kenmerken respondent:

Leeftijd respondent

0,04

$-0,02$

0,01

0,00

Geslacht respondent

4,01

0,67

0,00

Gemiddeld kwaliteit set

(1)

Mean log-likelihood $\quad-0,50$ 
Tabel A.5

Rank-order model: schattingsresultaten vakspecifieke beroepen Metaal

Coefficiënt Standaard fout $p$-waarde

Persoonskenmerken:

Leeftijd

Leeftijd kwadraat /100

Man

Hobby muziek

Hobby vertegenwoordigend / leidinggevend

Hobby sport

Hobby computers

Hobby sleutelen aan apparaten

0,09

$-0,13$

0,06

$-0,08$

$-0,12$

$-0,10$

$-0,16$

0,00

Opleidingskenmerken

Sectorspecifieke opleiding

Geen beroeps- of sectorspecifieke opleiding

Overschoold

Onderschoold

Opleiding via leerlingwezen

Kenmerken werkervaring

Werkervaring in aanverwant beroep $(<1$ jaar $)$

Werkervaring in aanverwant beroep ( $>1$ jaar)

Werkervaring in zelfde beroep $(<1$ jaar $)$

Werkervaring in zelfde beroep ( $>1$ jaar)

Kenmerken inactiviteit:

Werkloos $(<1$ jaar $)$

Werkloos ( $>1$ jaar)

Huisvrouw/man $(<1$ jaar $)$

Huisvrouw/man ( $>1$ jaar)

Student/scholier studeert binnenkort af

Mean log-likelihood $\quad-26,50$
$-0,12$

$-0,52$

$-0,10$

$-0,07$

0,07

0,39

0,69

1,22

1,03

$-0,03$

$-0,62$

$-0,26$

$-0,56$

0,05
0,06

0,06

0,08

0,11

0,16

0,19

0,13

0,13

0,15

0,05

0,28

0,32

0,26

0,24

0,12

0,49

0,13

0,17

0,12

0,18

0,00

0,30

0,16

0,34

0,09

0,23

0,18

0,01

0,11

0,26

0,00

0,11

0,00

0,34

0,46

0,24

0,00

0,28

0,18

0,14

0,00

0,23

0,41 
Tabel A.6

Logit model kans op acceptabel: schattingsresultaten vakspecifieke beroepen Metaal

Coefficiënt Standaard fout $p$-waarde

Constant

$\begin{array}{lll}-1,01 & 1,84 & 0,29\end{array}$

Persoonskenmerken:

Leeftijd

Leeftijd kwadraat/100

0,12

0,09

0,08

$-0,17$

0,13

0,10

Man

0,11

0,13

0,28

Hobby muziek

0,24

0,26

0,18

0,09

0,30

0,38

Hobby sport

0,21

0,09

Hobby computers

Hobby sleutelen aan apparaten

$-0,24$

0,22

0,13

0,01

0,21

0,47

Opleidingskenmerken:

Sectorspecifieke opleiding

$-0,18$

0,23

0,22

Geen beroeps- of sectorspecifieke opleiding

$-0,79$

0,22

0,00

Overschoold

$-0,05$

0,36

0,06

0,42

Opleiding via leerlingwezen

0,29

0,36

Kenmerken werkervaring:

Werkervaring in aanverwant beroep $(<1$ jaar $)$

Werkervaring in aanverwant beroep ( $>1$ jaar)

0,06

0,16

Werkervaring in zelfde beroep $(<1$ jaar $)$

Werkervaring in zelfde beroep ( $>1$ jaar)

0,92

0,34

0,00

1,08

0,19

0,00

1,63

0,42

0,00

1,75

0,24

0,00

Kenmerken inactiviteit:

Werkloos (< 1 jaar)

Werkloos (> 1 jaar)

0,45

0,56

0,21

$-1,07$

0,34

0,00

Huisvrouw/man ( $<1$ jaar)

0,09

0,45

0,42

$-1,03$

0,24

0,00

Student/scholier studeert binnenkort af

0,14

0,35

0,35

Functies:

(Boog)lasser

0,62

0,37

0,05

(Constructie)bankwerker

0,47

0,38

0,11

$-0,19$

0,39

0,31

Fijnbankwerker

$-0,12$

0,40

0,38

Kenmerken bedrijfsomvang:

10-99 werknemers

$-0,72$

0,20

0,00

Ontwikkeling bedrijf:

Afgelopen 12 maanden gegroeid

0,38

0,17

0,01

Kenmerken vacatures:

Moeilijk om vacatures op te vullen

0,31

0,19

0,05

Kenmerken respondent:

Leeftijd respondent

$-0,01$

$-0,47$

0,01

0,14

Respondent is personeelsfunctionaris

0,59

0,36

0,10

Respondent is directeur/eigenaar

Geslacht respondent

0,66

0,30

0,03

0,22

0,00

Andere kenmerken:

Gemiddeld kwaliteit set

$-1,85$

0,76

0,01

Mean log-likelihood $\quad-0,59$ 
Tabel A.7

Rank-order model: schattingsresultaten leidinggevende beroepen

Coefficiënt Standaard fout $\mathrm{p}$-waarde

Persoonskenmerken:

Leeftijd

Leeftijd kwadraat /100

Man

Hobby muziek

Hobby vertegenwoordigend / leidinggevend

Hobby sport

Hobby computers

Onderschoold

Kenmerken werkervaring:

Werkervaring in leidinggevend beroep $(<1$ jaar)

Werkervaring in leidinggevend beroep ( $>1$ jaar)

Werkervaring in aanverwant beroep $(<1$ jaar)

Werkervaring in aanverwant beroep ( $>1$ jaar)

Werkervaring in zelfde beroep $(<1$ jaar $)$

Werkervaring in zelfde beroep ( $>1$ jaar)

Kenmerken inactiviteit:

Werkloos $(<1$ jaar $)$

Werkloos (> 1 jaar)

Huisvrouw/man $(<1$ jaar $)$

Huisvrouw/man ( $>1$ jaar)

Student/scholier studeert binnenkort af
0,13

$-0,18$

0,03

$-0,30$

$-0,09$

0,06

$-0,16$

$-0,19$

$-0,28$

$-0,59$

0,37

$-0,17$

0,08

0,12

0,15

0,30

0,27

0,37

0,24

0,06

0,07

0,41

0,16

0,37

0,42

0,26

0,23

0,57

0,39

0,51

1,89

1,72

0,30

0,26

0,29

0,28

0,17

0,02

0,16

0,20

0,01

0,20

0,44

0,30

0,18

0,00

0,33

0,11

0,15

0,00

0,52

0,00

0,19

0,00

$-0,52$

$-1,06$

$-0,45$

$-0,17$

$-0,06$

0,65

0,21

0,34

0,00

0,30

0,07

0,19

0,18

0,35

0,43

Mean log-likelihood $\quad-25,33$ 
Tabel A.8

Logit model kans op acceptabel: schattingsresultaten leidinggevende beroepen

Coefficiënt Standaard fout p-waarde

Constante

$\begin{array}{lll}0,50 & 2,46 & 0,42\end{array}$

Persoonskenmerken:

Leeftijd

Leeftijd kwadraat /100

0,01

0,02

0,02

$-0,53$

Hobby muziek

$-0,32$

$-0,29$

0,15

0,12

0,47

Hobby vertegenwoordigend / leidinggevend

0,22

0,46

Hobby sport

0,38

0,47

Hobby computers

$0,36 \quad 0,19$

$0,32 \quad 0,18$

Opleidingskenmerken:

Sectorspecifieke opleiding

$-0,30$

0,32

0,32

Mamagement/bedrijfskunde opleiding

Geen sectorspecifieke of managementopleiding

$-0,39$

0,62

0,32

$-1,29$

0,52

0,23

Overschoold

0,89

0,57

0,01

0,00

Onderschoold

$-0,49$

0,33

Kenmerken werkervaring:

Werkervaring in leidinggevend beroep $(<1$ jaar)

Werkervaring in leidinggevend beroep ( $>1$ jaar)

Werkervaring in aanverwant beroep ( $<1$ jaar)

Werkervaring in aanverwant beroep ( $>1$ jaar)

Werkervaring in zelfde beroep $(<1$ jaar)

Werkervaring in zelfde beroep ( $>1$ jaar)

$-0,03$

1,14

0,96

1,20

3,61

3,08

$-2,40$

Kenmerken inactiviteit:

Werkloos $(<1$ jaar $)$

Werkloos ( $>1$ jaar)

Huisvrouw/man ( $<1$ jaar)

Huisvrouw/man ( $>1$ jaar)

Student/scholier studeert binnenkort af

Bedrijfssector:

Zorg

Metaal

$-0,84$

$-1,06$

$-0,74$

$-1,04$

1,21

0,61

0,27

0,41

0,25

0,88

0,51

0,07

Kenmerken bedrijfsomvang:

$<10$ werknemers

10-99 werknemers

Ontwikkeling bedrij:

Afgelopen 12 maanden gegroeid

Kenmerken vacatures:

Moeilijk om vacatures op te vullen

Kenmerken respondent

Leeftijd respondent

Respondent is personeelsfunctionaris

Respondent is (mede) directeur

Geslacht respondent

Andere kenmerken:

Gemiddeld kwaliteit set

$-0,54$

0,48

0,00

0,01

0,00

0,00

0,00

$-0,51$

$-0,11$

Mean log-likelihood $\quad-0,47$

$\begin{array}{rrr}0,01 & 0,02 & 0,16 \\ -0,45 & 0,44 & 0,16 \\ -1,80 & 0,45 & 0,00 \\ 0,34 & 0,24 & 0,08\end{array}$

$\begin{array}{lll}-1,46 & 1,45 & 0,16\end{array}$

0,16

0,00

0,08
1,14

0,53

0,64

0,34

0,50

0,57

0,40

0,07

0,00

0,02

0,00

0,10

0,06

0,41

0,18

$0,33 \quad 0,00$

$0,25 \quad 0,00$

$0,25 \quad 0,02$ 
Tabel A.9

Rank-order model: schattingsresultaten secretaresses

Coefficiënt Standaard fout p-waarde

Persoonskenmerken:

Leeftijd

Leeftijd kwadraat /100

Man

Hobby muziek

Hobby vertegenwoordigend / leidinggevend

Hobby sport

Opleidingskenmerken:

Sectorspecifieke opleiding

Geen beroeps- of sectorspecifieke opleiding

Overschoold

Onderschoold

Opleiding via leerlingwezen

Kenmerken werkervaring:

Werkervaring in aanverwant beroep $(<1$ jaar $)$

Werkervaring in aanverwant beroep ( $>1$ jaar)

Werkervaring in zelfde beroep $(<1$ jaar $)$

Werkervaring in zelfde beroep ( $>1$ jaar)

Werkervaring als secretaresse in de zorgsector

Werkervaring als secretaresse in de Metaal

Werkervaring als secretaresse in de IT

Kenmerken inactiviteit:

Werkloos $(<1$ jaar $)$

Werkloos ( $>1$ jaar)

Huisvrouw/man $(<1$ jaar $)$

Huisvrouw/man ( $>1$ jaar)

Student/scholier studeert binnenkort af
0,14

$-0,20$

$-0,53$

0,00

$-0,02$

$-0,23$

$-0,30$

$-0,83$

$-0,54$

$-0,14$

0,05

0,62

0,68

0,95

1,11

0,76

0,64

0,93

$-1,12$

$-0,15$

0,53

0,06

0,57
0,08

0,11

0,13

0,20

0,21

0,17

0,22

0,21

0,21

0,16

0,15

0,53

0,21

0,35

0,27

0,29

0,26

0,26

0,47

0,31

0,76

0,26

0,31
0,04

0,04

0,00

0,49

0,47

0,09

0,09

0,00

0,00

0,20

0,37

0,12

0,00

0,00

0,00

0,00

0,01

0,00

0,01

0,31

0,24

0,41

0,03

Mean log-likelihood -25,02 
Tabel A.10

Logit model kans op acceptabel: schattingsresultaten secretaresses

Coefficiënt Standaard fout $p$-waarde

Constante

$-3,30$

2,93

0,13

Persoonskenmerken:

Leeftijd

Leeftijd kwadraat /100

0,26

$-0,40$

0,14

0,03

Man

$-0,51$

$-0,26$

Hobby muziek

Hobby vertegenwoordigend / leidinggevend

$-0,92$

Hobby sport

$-0,53$

0,21

0,02

$0,30 \quad 0,04$

$0,36 \quad 0,23$

$0,38 \quad 0,01$

Opleidingskenmerken:

Sectorspecifieke opleiding

$-0,39$

$-1,35$

Overschoold

Onderschoold

$-0,80$

$-0,12$

Opleiding via leerlingwezen

0,50

0,29

0,03

Kenmerken werkervaring:

Werkervaring in aanverwant beroep $(<1$ jaar $)$

Werkervaring in aanverwant beroep ( $>1$ jaar)

Werkervaring in zelfde beroep $(<1$ jaar $)$

Werkervaring in zelfde beroep ( $>1$ jaar)

Werkervaring als secretaresse in de zorgsector

Werkervaring als secretaresse in de Metaal

Werkervaring als secretaresse in de IT

Kenmerken inactiviteit:

Werkloos $(<1$ jaar $)$

Werkloos ( $>1$ jaar)

Huisvrouw/man ( $<1$ jaar)

Huisvrouw/man ( $>1$ jaar)

Student/scholier studeert binnenkort af

1,30

1,79

1,89

2,95

0,93

2,42

1,12

0,42

0,18

0,42

0,00

0,39

0,02

0,33

0,36

0,29

0,04

Bedrijfssector:

Zorg

Metaal

$-0,46$

$-0,57$

0,43

$-0,41$

0,96

1,01

0,10

0,39

0,00

0,72

0,00

0,56

0,00

0,57

0,05

1,24

0,03

0,58

0,03

Kenmerken bedrijfsomvang:

$<10$ werknemers

10-99 werknemers

$-1,41$

$-0,78$

0,84

0,29

0,51

0,13

0,76

0,29

0,41

0,16

0,58

0,05

Ontwikkeling bedrijf:

Afgelopen 12 maanden gegroeid

0,01

$0,46 \quad 0,05$

Kenmerken vacatures:

Bedrijf heeft vacatures

Moeilijk om vacatures op te vullen

0,66

71,08

0,29

0,44

0,00

Kenmerken respondent:

Leeftijd respondent

Werkervaring respondent

Respondent is personeelsfunctionaris

Respondent is directeur/eigenaar

Geslacht respondent

0,31

0,02

0,35

0,71

0,31

0,54

0,32

0,04

0,06

0,03

0,01

0,01

0,02

0,28

0,40

0,65

0,27

0,33

0,58

0,29

1,51

0,38

0,00

Andere kenmerken:

Gemiddeld kwaliteit set

$-4,23$

1,20

0,00

Mean log-likelihood $\quad-0,47$ 


\section{Bijlage B: Functieomschrijvingen}

\section{IT}

Helpdeskmedewerker

Het zorgdragen voor de afhandeling van incidenten en/of problemen en het deels zelfstandig oplossen hiervan. Begeleiden van gebruikers om hard- en software optimaal te benutten (MBO-niveau).

Programmeur

Het ontwikkelen, schrijven of herschrijven van programma's of programma delen (HBOniveau).

Projectmanager

Het leidinggeven aan een project in zowel inhoudelijke als organisatorische zin. Het dragen van de verantwoordelijkheid voor de totale uitvoering van het project (HBO-niveau).

Projectadviseur

Het geven van advies met betrekking tot automatisering en het uitvoeren van automatiseringsonderzoeken (WO-niveau).

Systeemontwerper

Het ontwerpen en onderhouden van functionele informatiesystemen (WO-niveau).

Secretaresse/management assistent

Het dragen van de verantwoordelijkheid voor de administratieve en organisatorische ondersteuning van het management en de medewerkers.

\section{Zorg}

Medisch Secretaresse

Het zorg dragen voor de administratieve en organisatorische ondersteuning van één of meer medisch specialisten in een ziekenhuis.

Helpende

Het uitvoeren van zowel (lichte) lichamelijke als huishoudelijke zorg aan zieke, gehandicapte of oudere mensen. 
Zieken- of bejaardenverzorgende

Het vaststellen, plannen, uitvoeren en evalueren van zowel lichamelijke als huishoudelijke zorg aan zieke, gehandicapte of oudere mensen.

Medisch Analist

Het zelfstandig analyseren van lichaamsstoffen.

Verpleegkundige

Het vaststellen, plannen, uitvoeren en evalueren van de zorg aan zieke, gehandicapte of oudere mensen.

\section{Activiteitenbegeleider}

Organiseren van activiteiten voor patiënten. Dit betreft zowel activiteiten op het gebied van hobby en vrije tijd als activiteiten die zijn gericht op zelfredzaamheid.

Afdelingshoofd zieken-, verzorgings- of verpleegtehuis

Leiding geven aan een bepaalde dienst of afdeling van een ziekenhuis, verzorgingshuis of verpleeghuis.

\section{Metaal}

(Boog)lasser

Het doen van laswerk in de meest voorkomende lasposities aan de hand van instructies, tekeningen en lasprocedures.

(Constructie)bankwerker

Het maken van lichte tot middelzware constructiedelen van (roestvast) staal en aluminium met gebruikmaking van verschillende technieken als knippen, buigen, snijbranden en bankwerken.

\section{Bedrijfshoofd/Manager}

Het geven van leiding aan een afdeling of business unit.

\section{Monteur}

Montage en onderhoud aan machines, monteren van onderdelen en controleren van machines op een goede werking. Dit gebeurt aan de hand van technische tekeningen en normbladen. 
Secretaresse/Management assistent

Het dragen van de verantwoordelijkheid voor de administratieve en organisatorische ondersteuning van het management en de medewerkers.

\section{Fijnbankwerker}

Het maken van precisie-onderdelen voor machines, apparaten en gereedschappen.

Productiemedewerker

Bedienen van metaalbewerkingsmachines. 


\section{Bijlage C: Kansverdeling opleiding en vorige beroep}

Tabel C.1

Helpdeskmedewerker

kans

$\begin{array}{lr}\text { Opleiding } & \\ \text { MBO Netwerkbeheerder } & 0,125 \\ \text { MBO Netwerkbeheerder (LLW) } & 0,125 \\ \text { MBO ICT-beheerder } & 0,125 \\ \text { MBO ICT-beheerder (LLW) } & 0,125 \\ \text { MBO Assistent-marketing en communicatie } & 0,045 \\ \text { MBO Medewerker facilitaire dienstverlening } & 0,045 \\ \text { MBO Eerste monteur consumenten electronica } & 0,045 \\ \text { MBO Basisdrukker (LLW) } & 0,045 \\ \text { MBO Sociaal-juridisch medewerker } & 0,045 \\ \text { HBO Computertechniek } & 0,045 \\ \text { HBO Informatica en informatiekunde } & 0,045 \\ \text { HBO Modevormgeving } & 0,045 \\ \text { MAVO } & 0,045 \\ \text { HAVO } & 0,045 \\ \text { VWO } & 0,045 \\ \text { Huidige of laatste beroep } & \\ \text { Nooit gewerkt } & \\ \text { Helpdeskmedewerker } & 0,050 \\ \text { Junior programmeur } & 0,119 \\ \text { Computer operator } & 0,119 \\ \text { Netwerkbeheerder } & 0,119 \\ \text { Telemarketeer } & 0,119 \\ \text { Electronicamonteur } & 0,053 \\ \text { Verkoper electronica } & 0,053 \\ \text { Verkoper kleding } & 0,053 \\ \text { Postbesteller } & 0,053 \\ \text { Industrieel productiemedewerker } & 0,053 \\ \text { Vertegenwoordiger softwarebedrijf } & 0,053 \\ \text { Boekhouder } & 0,053 \\ \text { Administratief medewerker } & 0,053 \\ & 0,053\end{array}$




\section{Opleiding}

MBO Secretaresse

MBO Secretaresse (LLW)

MBO Directiesecr,/management assistant

MBO Directiesecr,/management assistent (LLW)

0,063

MBO Medisch secretaresse

MBO Medisch secretaresse (LLW)

0,063

HAVO

0,063

VWO

0,063

MBO Bedrijfsadministratief medewerker (LLW)

0,063

0,050

MBO Logistiek medwerker - materiaal management $\quad 0,050$

MBO Assistent secretaresse

MBO Assistent secretaresse (LLW)

0,050

0,050
0,050

MBO Facilitaire dienstverlening

MBO Medewerker recreatie

HBO Economisch-linguistische opleiding

0,050

HBO Leraar geschiedenis VO, 1e graads

0,050

0,050

WO Engels

0,050

VMBO algemeen beveiligingsmedewerker

0,050

Huidige of laatste beroep

Nooit gewerkt

Secretaresse binnen IT-sector

0,050

Secretaresse buiten IT-sector

0,053

Directiesecretaresse binnen IT-sector

0,053

0,053

Directiesecretaresse buiten IT-sector

Managementassistent binnen IT-sector

0,053

Managementassistent buiten IT-sector

0,053

Administratief medewerker binnen IT-sector

0,053

Administratief medewerker buiten IT-sector

0,053

Medisch secretaresse

0,053

Verkoper detailhandel

0,048

Steward (luchtvaart)

0,048

Zweminstructeur

Medewerker peuterspeelzaal

0,048

Bankemployee

Caissiere

0,048

Freelance journalist

0,048

Receptionist

0,048

Serveerder

0,048

Schoonmaker

0,048 
Tabel C.3

Programmeur

kans

Opleiding

HBO Informatica en informatiekunde

0,125

HBO Bedrijfskundige informatica

0,125

WO Informatica

WO Econometrie

0,125

MBO Applicatie ontwikkelaar

MBO Applicatie ontwikkelaar (LLW)

0,125

0,033

MBO ICT beheerder

0,033

0,033

MBO ICT beheerder (LLW)

0,033

HBO Communicatiesystemen

0,033

HBO Autotechniek

0,033

HBO Computertechniek

0,033

HBO Technische bedrijfskunde

0,033

HBO Electrotechniek

0,033

HBO Leraar geschiedenis

0,033

WO Sociale geografie

0,033

WO Engelse taal en letterkunde

0,033

MAVO

HAVO

0,033

0,033

VWO

0,033

Huidige of laatste beroep

Nooit gewerkt

0,050

Programmeur

0,237

Junior programmeur

0,237

Websitebouwer

0,043

Helpdeskmedewerker

0,043

Netwerkbeheerder

0,043

Verkoper soft- en hardware

0,043

Journalist

0,043

Vertaler

0,043

Electromonteur

0,043

Administratief medewerker

0,043

Boekhouder

0,043

PR-functionaris

0,043

Medewerker salarisadministratie

0,043 
Opleiding

HBO Informatica en informatiekunde

0,125

HBO Bedrijfskundige informatica

0,125

HBO Internationaal management

0,125

HBO Management economie en recht

0,125

MBO ICT beheerder

MBO ICT beheerder (LLW)

0,038

HBO Autotechniek

HBO Commerciele economie

0,038

HBO Economisch-linguistisch

Jopleiding

0,038

HBO Journalistiek

WO Informatica

0,038

WO Bedrijfskunde

0,038

WO Bedriifseconomie

0,038

WO Engels

WO Geschiedenis

0,038

HAVO

0,038

0,038

VWO

0,038

Huidige of laatste beroep

Nooit gewerkt

0,050

Manager grootwinkelbedrijf

0,079

Bedrijfsleider PC-shop

0,079

Projectleider onderzoeksinstituut

0,079

Projectmanager ICT

0,079

Programmeur

0,079

Adviseur automatisering

0,079

Assistent manager

Medewerker econ, adviesbureau

0,053

0,053

Journalist

Medewerker onderzoeksinstituut

0,053

0,053

Vertegenwoordiger

0,053

Gemeentelijk ambtenaar

0,053

PR-functionaris

0,053

Administratief medewerker

0,053

Systeemontwerper

0,053 
Tabel C.5

Projectadviseur

kans

Opleiding

WO Informatica

0,125

WO Bestuursinformatietechnologie

0,125

WO Bestuurlijke informatiekunde

0,125

WO Bedrijfsgerichte informatica

0,125

HBO Bedrijfskundige informatica

0,042

HBO Voeding en marketing

HBO Sociaal pedagogische hulpverlening

0,042

0,042

WO Bedrijfskunde

WO Technische wiskunde

0,042

0,042

WO Econometrie

WO Technische bedrijfswetenschappen

0,042

WO Frans

WO Sociale geografie

HAVO

VWO

0,042

0,042

0,042

0,042

0,042

HEAO

0,042

Huidige of laatste beroep

Nooit gewerkt

0,050

Projectadviseur ICT

0,237

Technisch adviseur

0,237

Manager Verzekeringsbedrijf

0,053

Manager Bankwezen

0,053

Bedrijfsleider PC-shop

0,053

Systeemontwerper

0,053

Economisch adviseur

0,053

Leraar VO, informatiekunde

0,053

Systeemontwerper

0,053

Programmeur

0,053

Projectmanager

0,053

Administratief medewerker

0,000 
Tabel C.6

Systeemontwerper

kans

Opleiding

WO Informatica $\quad 0,125$

WO Bestuursinformatietechnologie $\quad 0,125$

WO Bestuurlijke informatiekunde $\quad 0,125$

WO Bedrijfsgerichte informatica $\quad 0,125$

$\begin{array}{ll}\text { HBO Informatica en informatiekunde } & 0,045\end{array}$

HBO Bedrijfskundige informatica $\quad 0,045$

HBO Logistiek en economie $\quad 0,045$

HBO Theatertechniek $\quad 0,045$

WO Econometrie $\quad 0,045$

WO Nederlands recht $\quad 0,045$

WO Vrijetijdswetenschappen $\quad 0,045$

VWO

HEAO

WO Economie

0,045

0,045

0,045

Huidige of laatste beroep

Nooit gewerkt

0,050

Systeemontwerper

0,237

0,237

Programmeur

0,040

Projectadviseur ICT

0,040

Administratief medewerker

0,040

Manager Verzekeringsbedrijf

0,040

Manager Bankwezen

0,040

Bedrijfsleider PC-shop

0,040

Journalist

Verkoper hard- en software

0,040

Economisch onderzoeker

0,040

0,040

Vertegenwoordiger software

0,040

Projectmanager

0,040

Informatiemanager

0,040 
Tabel C.7

Medisch secretaresse

kans

Opleiding

MBO Medisch secretaresse

MBO Medisch secretaresse (LLW)

0,083

MBO Secretaresse

MBO Secretaresse (LLW)

MBO Directiesecr,/management assistent

0,083

0,083

0,083

MBO Directiesecr,/management assistent (LLW)

0,083

HAVO

VWO

MBO Doktersassistent

0,042

0,042

0,042

MBO Apothekersassistent

MBO Bedriifsadministratief medewerker (LLW)

0,042

MBO Logistiek medewerker - materiaal management

0,042

MBO Assistent secretaresse

MBO Assistent secretaresse (LLW)

HBO Kaderopleiding gezondheidszorg

0,042

0,042

0,042

HBO Economisch-linguistische opleiding

0,042

0,042

HBO Leraar geschiedenis VO, 1 e graads

0,042

WO Engels

0,042

Huidige of laatste beroep

Nooit gewerkt

0,050

Medisch secretaresse

0,053

Secretaresse binnen gezondheidszorg

0,053

Secretaresse buiten gezondheidszorg

0,053

Directiesecretaresse binnen gezondheidszorg

0,053

Directiesecretaresse buiten gezondheidszorg

0,053

Managementassistent binnen gezondheidszorg

0,053

Managementassistent buiten gezondheidszorg

0,053

Administratief medewerker binnen gezondheidszorg

0,053

Administratief medewerker buiten gezondheidszorg

0,053

Verkopermedewerker apotheek

0,048

Steward (luchtvaart)

Zweminstructeur

0,048

Medewerker peuterspeelzaal

0,048

Bankemployee

0,048

Caissiere

0,048

Freelance journalist

0,048

Receptionist

0,048

Serveerder

0,048

Schoonmaker

0,048

0,048 


\begin{tabular}{|c|c|}
\hline $\begin{array}{l}\text { Opleiding } \\
\text { MBO Helpende } \\
\text { MBO Helpende (LLW) } \\
\text { MBO Verzorgende } \\
\text { MBO Verzorgende (LLW) } \\
\text { MBO Verpleegkundige (klinische zorg) } \\
\text { MBO Verpleegkundige (chronisch zieken) } \\
\text { MBO Verpleegkundige (psychiatrie) } \\
\text { MBO Verpleegkundige (verst, gehandicapten) } \\
\text { MBO Verpleegkundige (LLW, klinische zorg) } \\
\text { MBO Verpleegkundige (LLW, chronisch zieken) } \\
\text { MBO Verpleegkundige (LLW, psychiatrie) } \\
\text { MBO Verpleegkundige (LLW, verst, gehandicapten) } \\
\text { HBO Verpleegkundige (klinische zorg) } \\
\text { HBO Verpleegkundige (chronisch zieken) } \\
\text { HBO Verpleegkundige (psychiatrie) } \\
\text { MAVO } \\
\text { HAVO } \\
\text { VWO } \\
\text { MBO Activiteitenbegeleider } \\
\text { MBO Activiteitenbegeleider (LLW) } \\
\text { MBO Sociaal pedagogisch medewerker } \\
\text { MBO Secretaresse } \\
\text { MBO Secretaresse (LLW) } \\
\text { MBO Schoonheidsspecialiste } \\
\text { MBO Facilitaire dienstverlening } \\
\text { MBO Bedrijfsadministratie } \\
\text { HBO Ergotherapie } \\
\text { HEAO }\end{array}$ & $\begin{array}{l}0,050 \\
0,050 \\
0,050 \\
0,050 \\
0,050 \\
0,050 \\
0,050 \\
0,050 \\
0,050 \\
0,050 \\
0,050 \\
0,050 \\
0,050 \\
0,050 \\
0,050 \\
0,019 \\
0,019 \\
0,019 \\
0,019 \\
0,019 \\
0,019 \\
0,019 \\
0,019 \\
0,019 \\
0,019 \\
0,019 \\
0,019 \\
0,019\end{array}$ \\
\hline $\begin{array}{l}\text { Huidige of laatste beroep } \\
\text { Nooit gewerkt } \\
\text { Helpende } \\
\text { Verzorgende } \\
\text { Bejaardenverzorgende } \\
\text { Gezinsverzorgende } \\
\text { Ziekenverzorgende } \\
\text { Kraamverzorgende } \\
\text { Verpleegkundige } \\
\text { Secretaresse } \\
\text { Medisch secretaresse } \\
\text { Medewerker peuterspeelzaal } \\
\text { Administratief medewerker } \\
\text { Receptionist } \\
\text { Telefonist } \\
\text { Medewerker salarisadministratie } \\
\text { Serveerder } \\
\text { Verkopermedewerker apotheek } \\
\text { Verkoper kleding } \\
\text { Conducteur } \\
\text { Activiteitenbegeleider } \\
\text { Programmeur } \\
\text { Vertaler }\end{array}$ & $\begin{array}{l}0,050 \\
0,090 \\
0,090 \\
0,090 \\
0,090 \\
0,090 \\
0,090 \\
0,090 \\
0,023 \\
0,023 \\
0,023 \\
0,023 \\
0,023 \\
0,023 \\
0,023 \\
0,023 \\
0,023 \\
0,023 \\
0,023 \\
0,023 \\
0,023 \\
0,023\end{array}$ \\
\hline
\end{tabular}




\begin{tabular}{|c|c|}
\hline $\begin{array}{l}\text { Opleiding } \\
\text { MBO Helpende } \\
\text { MBO Helpende (LLW) } \\
\text { MBO Verzorgende } \\
\text { MBO Verzorgende (LLW) } \\
\text { MBO Verpleegkundige (klinische zorg) } \\
\text { MBO Verpleegkundige (chronisch zieken) } \\
\text { MBO Verpleegkundige (psychiatrie) } \\
\text { MBO Verpleegkundige (verst, gehandicapten) } \\
\text { MBO Verpleegkundige (LLW, klinische zorg) } \\
\text { MBO Verpleegkundige (LLW, chronisch zieken) } \\
\text { MBO Verpleegkundige (LLW, psychiatrie) } \\
\text { MBO Verpleegkundige (LLW, verst, gehandicapten) } \\
\text { HBO Verpleegkundige (klinische zorg) } \\
\text { HBO Verpleegkundige (chronisch zieken) } \\
\text { HBO Verpleegkundige (psychiatrie) } \\
\text { MAVO } \\
\text { HAVO } \\
\text { VWO } \\
\text { MBO Activiteitenbegeleider } \\
\text { MBO Activiteitenbegeleider (LLW) } \\
\text { MBO Sociaal-pedagogisch werker } \\
\text { MBO Secretaresse } \\
\text { MBO Secretaresse (LLW) } \\
\text { MBO Schoonheidsspecialiste } \\
\text { MBO Medewerker facilitaire dienstverlening } \\
\text { MBO Bedrijfsadministratie } \\
\text { HBO Ergotherapie } \\
\text { HEAO }\end{array}$ & $\begin{array}{l}0,050 \\
0,050 \\
0,050 \\
0,050 \\
0,050 \\
0,050 \\
0,050 \\
0,050 \\
0,050 \\
0,050 \\
0,050 \\
0,050 \\
0,050 \\
0,050 \\
0,050 \\
0,019 \\
0,019 \\
0,019 \\
0,019 \\
0,019 \\
0,019 \\
0,019 \\
0,019 \\
0,019 \\
0,019 \\
0,019 \\
0,019 \\
0,019\end{array}$ \\
\hline $\begin{array}{l}\text { Huidige of laatste beroep } \\
\text { Nooit gewerkt } \\
\text { Helpende } \\
\text { Verzorgende } \\
\text { Bejaardenverzorgende } \\
\text { Gezinsverzorgende } \\
\text { Ziekenverzorgende } \\
\text { Kraamverzorgende } \\
\text { Verpleegkundige } \\
\text { Secretaresse } \\
\text { Medisch secretaresse } \\
\text { Medewerker peuterspeelzaal } \\
\text { Administratief medewerker } \\
\text { Receptionist } \\
\text { Telefonist } \\
\text { Medewerker salarisadministratie } \\
\text { Serveerder } \\
\text { Verkopermedewerker apotheek } \\
\text { Verkoper kleding } \\
\text { Conducteur } \\
\text { Activiteitenbegeleider } \\
\text { Programmeur } \\
\text { Vertaler }\end{array}$ & $\begin{array}{l}0,050 \\
0,090 \\
0,090 \\
0,090 \\
0,090 \\
0,090 \\
0,090 \\
0,090 \\
0,023 \\
0,023 \\
0,023 \\
0,023 \\
0,023 \\
0,023 \\
0,023 \\
0,023 \\
0,023 \\
0,023 \\
0,023 \\
0,023 \\
0,023 \\
0,023\end{array}$ \\
\hline
\end{tabular}


Tabel C.10

Medisch analist

kans

Opleiding

MBO Medische laboratoriumtechniek

0,150

MBO Biologische laboratoriumtechniek

0,150

MBO Laborant

0,150

HBO Medisch laboratorium

0,150

HBO Biologisch laboratorium

0,150

HAVO

0,016

VWO

MBO Procesoperator C

0,016

0,016

MBO Mechanisch operator A

0,016

MBO Procestechniek

0,016

MBO Materiaaltechnologie

0,016

MBO Bedrijfsadministratie

0,016

HBO Radiologie

0,016

HBO Biotechnologie

HBO Chemische laboratoriumopleiding

0,016

HBO Proceskunde

HBO Technische scheikunde

0,016

0,016

HBO Wiskunde

HEAO

0,016

0,016

WO Scheikunde

0,016

0,016

WO Wiskunde

0,016

Huidige of laatste beroep

Nooit gewerkt

0,050

Medisch analist

0,127

Technisch analist

0,127

Laborant

0,127

Biotechnisch laborant

0,127

Biotechnisch laboratorium medewerker

0,127

Biofarmaceutisch onderzoeker

0,021

Scheikundig onderzoeker

0,021

Administratief medewerker

0,021

Boekhouder

0,021

Kok

0,021

0,021

Cafe-eigenaar

0,021

0,021

Vertegenwoordiger farmaceutisch bedrijf

Artsenbezoeker

0,02

Verkoopmedewerker apotheek

0,021

Programmeur

0,021

0,021

Leraar scheikunde

Proefdierverzorger

0,021

Verzekeringsagent

0,021

Financieel adviseur

0,021 
Tabel C.11

Verpleegkundige

kans

\begin{tabular}{|c|c|}
\hline $\begin{array}{l}\text { Opleiding } \\
\text { MBO Verpleegkundige (klinische zorg) } \\
\text { MBO Verpleegkundige (chronisch zieken) } \\
\text { MBO Verpleegkundige (psychiatrie) } \\
\text { MBO Verpleegkundige (verst, gehandicapten) } \\
\text { MBO Verpleegkundige (LLW, klinische zorg) } \\
\text { MBO Verpleegkundige (LLW, chronisch zieken) } \\
\text { MBO Verpleegkundige (LLW, psychiatrie) } \\
\text { MBO Verpleegkundige (LLW, verst, gehandicapten) } \\
\text { MBO Praktijkopleider (na MBO verpleegkundige) } \\
\text { HBO Verpleegkundige (chronisch zieken) } \\
\text { HBO Verpleegkundige (psychiatrie) } \\
\text { HBO Verpleegkundige (maatsch,gezondheidszorg) } \\
\text { HBO Verpleegkundige (klinische zorg) } \\
\text { VWO } \\
\text { MBO Helpende } \\
\text { MBO Helpende (LLW) } \\
\text { MBO Verzorgende } \\
\text { MBO Verzorgende (LLW) } \\
\text { MBO Activiteitenbegeleider } \\
\text { MBO Activiteitenbegeleider (LLW) } \\
\text { MBO Sociaal-pedagogisch werker } \\
\text { MBO Schoonheidsspecialist } \\
\text { MBO Medewerker facilitaire dienstverlening } \\
\text { MBO Secretaresse } \\
\text { MBO Secretaresse (LLW) } \\
\text { HBO Creatieve therapie } \\
\text { HBO Maatschappelijk werk } \\
\text { HBO Ergotherapie } \\
\text { HBO Logopedie }\end{array}$ & $\begin{array}{l}0,058 \\
0,058 \\
0,058 \\
0,058 \\
0,058 \\
0,058 \\
0,058 \\
0,058 \\
0,058 \\
0,058 \\
0,058 \\
0,058 \\
0,058 \\
0,016 \\
0,016 \\
0,016 \\
0,016 \\
0,016 \\
0,016 \\
0,016 \\
0,016 \\
0,016 \\
0,016 \\
0,016 \\
0,016 \\
0,016 \\
0,016 \\
0,016 \\
0,016\end{array}$ \\
\hline $\begin{array}{l}\text { Huidige of laatste beroep } \\
\text { Nooit gewerkt } \\
\text { Verzorgende } \\
\text { Verpleegkundige } \\
\text { Wijkverpleegkundige } \\
\text { Afdelingshoofd psychiatrische instelling } \\
\text { Afdelingshoofd verpleegafdeling ziekenhuis } \\
\text { Afdelingshoofd verpleegtehuis } \\
\text { Afdelingshoofd verzorgingstehuis } \\
\text { Secretaresse } \\
\text { Medisch secretaresse } \\
\text { Managementsassistent } \\
\text { Verkoopmedewerker } \\
\text { Receptionist } \\
\text { Telefonist } \\
\text { Serveerder } \\
\text { Eigenaar kinderkledingzaak } \\
\text { Verkoper kleding } \\
\text { Verkoper boekhandel } \\
\text { Medewerker peuterspeelzaal } \\
\text { Activiteitenbegeleider } \\
\text { Bibliotheekmedewerker } \\
\text { Medewerker salarisadministratie } \\
\text { Administratief medewerker }\end{array}$ & $\begin{array}{l}0,050 \\
0,090 \\
0,090 \\
0,090 \\
0,090 \\
0,090 \\
0,090 \\
0,090 \\
0,021 \\
0,021 \\
0,021 \\
0,021 \\
0,021 \\
0,021 \\
0,021 \\
0,021 \\
0,021 \\
0,021 \\
0,021 \\
0,021 \\
0,021 \\
0,021 \\
0,021\end{array}$ \\
\hline
\end{tabular}


Tabel C.12

Activiteitenbegeleider

kans

$\begin{array}{lr}\text { Opleiding } & \\ \text { MBO Activiteitenbegeleider } & 0,250 \\ \text { MBO Activiteitenbegeleider (LLW) } & 0,250 \\ \text { HAVO } & 0,020 \\ \text { VWO } & 0,020 \\ \text { MBO Verpleegkundige (klinische zorg) } & 0,020 \\ \text { MBO Verpleegkundige (chronisch zieken) } & 0,020 \\ \text { MBO Verpleegkundige (psychiatrie) } & 0,020 \\ \text { MBO Verpleegkundige (verst, gehandicapten) } & 0,020 \\ \text { MBO Verpleegkundige (LLW, klinische zorg) } & 0,020 \\ \text { MBO Verpleegkundige (LLW, chronisch zieken) } & 0,020 \\ \text { MBO Verpleegkundige (LLW, psychiatrie) } & 0,020 \\ \text { MBO Verpleegkundige (LLW, verst, gehandicapten) } & 0,020 \\ \text { MBO Praktijkopleider (na MBO verpleegkundige) } & 0,020 \\ \text { MBO Verzorgende } & 0,020 \\ \text { MBO Verzorgende (LLW) } & 0,020 \\ \text { MBO Sociaal-pedagogisch werker } & 0,020 \\ \text { HBO Kaderopleiding gezondheidszorg } & 0,020 \\ \text { HBO Verpleegkundige (chronisch zieken) } & 0,020 \\ \text { HBO Verpleegkundige (psychiatrie) } & 0,020 \\ \text { HBO Verpleegkundige (maatsch, gezondheidszorg) } & 0,020 \\ \text { HBO Verpleegkundige (klinische zorg) } & 0,020 \\ \text { HBO Maatschappelijk werk } & 0,020 \\ \text { HBO Creatieve therapie } & 0,020 \\ \text { HBO Ergotherapie } & 0,020 \\ \text { HBO Leraar handvaardigheid } & 0,020 \\ \text { HBO Beeldende kunst en vormgeving } & 0,020 \\ \text { HBO Leraar muziek } & 0,020\end{array}$

Huidige of laatste beroep

Nooit gewerkt

0,050

Activiteitenbegeleider

0,475

Groepsleider jeugdwerk $\quad 0,022$

Verzorgende

Verpleegkundige

0,022

Wijkverpleegkundige

0,022

0,022

Secretaresse

0,022

Medisch secretaresse

0,022

Managementsassistent

0,022

Verkoopmedewerker

0,022

Receptionist

0,022

Telefonist

0,022

Serveerder

0,022

$\begin{array}{ll}\text { Eigenaar kinderkledingzaak } & 0,022\end{array}$

Verkoper kleding

0,022

Verkoper boekhandel

0,022

Medewerker peuterspeelzaal $\quad 0,022$

$\begin{array}{ll}\text { Bibliotheekmedewerker } & 0,022\end{array}$

Medewerker salarisadministratie $\quad 0,022$

$\begin{array}{ll}\text { Administratief medewerker } & 0,022\end{array}$

Zanger $\quad 0,022$

Zelfstandig kunstenaar $\quad 0,022$

Muziektherapeut $\quad 0,022$

$\begin{array}{ll}\text { Creatief therapeut } & 0,022\end{array}$ 
Tabel C.13

Afdelingshoofd zieken/verzorgingshuis

kans

\begin{tabular}{|c|c|}
\hline $\begin{array}{l}\text { Opleiding } \\
\text { MBO Verpleegkundige (klinische zorg) } \\
\text { MBO Verpleegkundige (chronisch zieken) } \\
\text { MBO Verpleegkundige (psychiatrie) } \\
\text { MBO Verpleegkundige (verst, gehandicapten) } \\
\text { MBO Verpleegkundige (LLW, klinische zorg) } \\
\text { MBO Verpleegkundige (LLW, chronisch zieken) } \\
\text { MBO Verpleegkundige (LLW, psychiatrie) } \\
\text { MBO Verpleegkundige (LLW, verst, gehandicapten) } \\
\text { MBO Praktijkopleider (na MBO verpleegkundige) } \\
\text { HBO Kaderopleiding gezondheidszorg } \\
\text { HBO Verpleegkundige (klinische zorg) } \\
\text { HBO Verpleegkundige (chronisch zieken) } \\
\text { HBO Verpleegkundige (psychiatrie) } \\
\text { HBO Verpleegkundige (maatsch,gezondheidszorg) } \\
\text { HAVO } \\
\text { VWO } \\
\text { MBO Verzorgende } \\
\text { MBO Verzorgende (LLW) } \\
\text { MBO Activiteitenbegeleider } \\
\text { MBO Activiteitenbegeleider (LLW) } \\
\text { MBO Sociaal-pedagogisch werker } \\
\text { HBO Maatschappelijk werk } \\
\text { HBO Creatieve therapie } \\
\text { HBO Ergotherapie } \\
\text { HBO Logopedie } \\
\text { HBO Bedrijfseconomie } \\
\text { HBO Bedrijfskunde } \\
\text { WO Gezondheidswetenschappen (beleid en beheer) } \\
\text { WO Gezondheidswetenschappen (verplegingswetenschap) } \\
\text { WO Gezondheidswetenschappen (arbeid en gezondheid) } \\
\text { WO Psychologie } \\
\text { WO Basisarts }\end{array}$ & $\begin{array}{l}0,054 \\
0,054 \\
0,054 \\
0,054 \\
0,054 \\
0,054 \\
0,054 \\
0,054 \\
0,054 \\
0,054 \\
0,054 \\
0,054 \\
0,054 \\
0,054 \\
0,014 \\
0,014 \\
0,014 \\
0,014 \\
0,014 \\
0,014 \\
0,014 \\
0,014 \\
0,014 \\
0,014 \\
0,014 \\
0,014 \\
0,014 \\
0,014 \\
0,014 \\
0,014 \\
0,014 \\
0,014\end{array}$ \\
\hline $\begin{array}{l}\text { Huidige of laatste beroep } \\
\text { Nooit gewerkt } \\
\text { Verpleegkundige } \\
\text { Wijkverpleegkundige } \\
\text { Afdelingshoofd psychiatrische instelling } \\
\text { Afdelingshoofd verpleegafdeling ziekenhuis } \\
\text { Afdelingshoofd verpleegtehuis } \\
\text { Afdelingshoofd verzorgingstehuis } \\
\text { Groepsleider jeugdwerk } \\
\text { Afdelingshoofd personeelsadministratie } \\
\text { Hoofd secretariaat } \\
\text { Directiesecretaresse } \\
\text { Activiteitenbegeleider } \\
\text { Verzorgende } \\
\text { Medisch secretaresse } \\
\text { Hoofd salarisadministratie } \\
\text { Creatief therapeut } \\
\text { Medewerker salarisadministratie } \\
\text { Administratief medewerker }\end{array}$ & $\begin{array}{l}0,050 \\
0,158 \\
0,158 \\
0,079 \\
0,079 \\
0,079 \\
0,079 \\
0,029 \\
0,029 \\
0,029 \\
0,029 \\
0,029 \\
0,029 \\
0,029 \\
0,029 \\
0,029 \\
0,029 \\
0,029\end{array}$ \\
\hline
\end{tabular}


Tabel C.14

(Boog) lasser

kans

Opleiding

MBO Aspirant lasser

0,167

MBO Aspirant lasser (LLW)

0,167

MBO Booglasser (LLW)

0,167

MBO Metaalkunde

0,167

VBO Mechanische techniek

0,028

VBO Constructiebankwerker

0,028

MBO Machinaal verspaner

0,028

MBO Machinaal verspaner (LLW)

0,028

MBO Fijnmechanische techniek

0,028

MBO Plaat en constructiewerker

0,028

MBO Plaat en constructiewerker (LLW)

0,028

HBO Werktuigbouwkunde

0,028

MAVO

HAVO

MBO Vliegtuigbouwer Metaal (LLW)

0,028

0,028

0,028

HBO Computertechniek

0,028

Huidige of laatste beroep

Nooit gewerkt

0,050

Booglasser

0,158

Aspirant lasser

0,158

Elektrisch booglasser

0,158

Constructiewerker/lasser

0,158

Metaalarbeider

0,021

Machinaal verspaner

0,021

Constructiebankwerker

0,021

Constructiebankwerker stalen ramen

0,021

Constructie- en apparatenbouwer

0,021

Eerste monteur industrieel onderhoud

0,021

Smid

0,021

Pijpmonteur

0,021

Fijnbankwerker

0,021

Metaalgieter

0,021

Postbesteller

0,021

Vakkenvuller

0,021

Cassiere

0,021

Vuilnisman

0,021

Schoonmaker

0,021 
Tabel C.15

Constructiebankwerker

kans

Opleiding

MBO Constructiebankwerker/lasser (LLW)

0,111

MBO Assistent constructiewerker/lasser

0,111

MBO Assistent constructiewerker/lasser (LLW)

0,111

MBO Plaat en constructiewerker

0,111

MBO Plaat en constructiewerker (LLW)

0,111

MBO Plaatwerker (LLW)

IVBO Mechanische techniek

0,111

0,026

VBO Mechanische techniek

0,026

MBO Productiemedewerker plaatwerken

0,026

MBO Productiemedewerker plaatwerken (LLW)

0,026

MBO Machinebankwerker fijnmechanisch (LLW)

0,026

MBO Machinebankwerker werktuigbouw (LLW)

0,026

MBO Machinaal verspaner

MBO Machinaal verspaner (LLW)

HBO AOT-techniek

0,026

0,026

MAVO

HAVO

MBO Vliegtuigbouwer Metaal (LLW)

0,026

0,026

0,026

0,026

HBO Computertechniek

0,026

Huidige of laatste beroep

Nooit gewerkt

0,050

Constructiebankwerker

0,158

Constructiebankwerker stalen ramen

0,158

Constructiebankwerker lasser

0,158

Constructie- en apparatenbouwer

0,158

Metaalarbeider

0,026

Machinaal verspaner

0,026

Eerste monteur industrieel onderhoud $\quad 0,026$

Smid

0,026

Pijpmonteur

0,026

Fijnbankwerker

0,026

Metaalgieter

0,026

Postbesteller

0,026

Vakkenvuller

0,026

Cassiere

0,026

Vuilnisman

0,026

Schoonmaker

0,026 
Tabel C.16

Bedrijfshoofd/manager

kans

Opleiding

MBO Booglasser (LLW)

MBO Constructiebankwerker/lasser (LLW)

0,095

MBO Machinaal verspaner

MBO Machinaal verspaner (LLW)

0,095

MBO Machinebankwerker fijnmechanisch (LLW)

0,095

0,095

HBO Bedrijfskunde

WO Bedrijfskunde

0,095

0,095

MAVO

HAVO

0,020

0,020

VWO

0,020

MBO Aspirant lasser

0,020

MBO Aspirant lasser (LLW)

0,020

MBO Operationele techniek

0,020

MBO Medewerker facilitaire dienstverlening

0,020

HBO Civiele techniek

0,020

HBO Computertechniek

0,020

HBO Communicatie

0,020

HBO Electrotechniek

0,020

HBO Management, economie en recht

0,020

HBO Bouwtechnische bedrijfskunde

0,020

WO Internationale bedrijfskunde

0,020

WO Techniek en maatschappij

0,020

WO Mechanica en constructies

0,020

WO Elektrotechniek

0,020

Huidige of laatste beroep

Nooit gewerkt

0,050

0,090

Bedrijfshoofd metaalbewerkingsbedrijf

0,090

Bedrijfsleider metaalbewerkingsbedrijf

0,090

Constructiebankwerker

0,090

Machinaal verspaner

0,090

Fijnbankwerker

Office manager

0,090

0,090

0,040

Hoofdwerktuigkundige

0,040

Productieplanner

0,040

Productieplanner

0,040

位

0,040

Economisch adviseur

0,040

ogrammeur

0,040

Bedrijfsleider bouwmarkt

Boekhouder

0,040 
Tabel C.17

Monteur

kans

Opleiding

MBO Monteur montage/onderhoud

0,111

MBO Monteur montage/onderhoud (LLW)

0,111

MBO Operationele techniek

0,111

MBO Eerste monteur industieel onderhoud (LLW)

0,111

MBO Productietechnisch vakkracht (LLW)

0,111

MBO Eerste productietechnisch vakkracht (LLW)

0,111

IVBO Mechanische techniek

VBO Mechanische techniek

0,022

0,022

0,022

VBO Constructiebankwerken

MBO Productiemedewerker plaatwerken

MBO Productiemedewerker plaatwerken (LLW)

0,022

MBO Constructiebankwerker/lasser (LLW)

0,022

0,022

MBO Gereedschapsmaker

MBO Fijnmechanische techniek (LLW)

MBO Machinebankwerker werktuigbouw (LLW)

0,022

0,022

0,022

HBO Werktuigbouwkunde

HBO AOT-techniek

0,022

0,022

0,022

MAVO

HAVO

MBO Vliegtuigbouwer Metaal (LLW)

0,022

0,022

HBO Computertechniek

Huidige of laatste beroep

Nooit gewerkt

0,050

Monteur machines

0,106

Monteur fabrieksinstallaties

0,106

Onderhoudsmonteur kantoor-, huishoudnaaimachines

0,106

Automonteur

0,106

Storingsmonteur

0,106

Motormonteur

0,106

Carrosseriebouwer

0,023

0,023

Boormachinist

0,023

Electronicamonteur

0,023

Wegenbouwmachinist

0,023

Meubelmaker

0,023

Metaalgieter

0,023

Lasser

0,023

Constructiebankwerker

0,023

Monteur systeembouw

0,023

0,023

Vakkenvuller

Vuilnisman

0,023

Caissiere

Schoonmaker 
Tabel C.18

Secretaresse/managementsassistente

kans

Opleiding

MBO Secretaresse

0,063

MBO Secretaresse (LLW)

0,063

MBO Directiesecr,/management assistent

0,063

MBO Directiesecr,/management assistent (LLW)

0,063

MBO Medisch secretaresse

MBO Medisch secretaresse (LLW)

0,063

HAVO

0,063

VWO

0,063

MBO Bedrijfsadministratief medewerker (LLW)

0,063

0,050

MBO Logistiek medewerker - materiaal management $\quad 0,050$

MBO Assistent secretaresse

MBO Assistent secretaresse (LLW)

0,050

0,050

MBO Facilitaire dienstverlening

MBO Medewerker recreatie

HBO Economisch-linguistische opleiding

0,050

0,050

HBO Leraar geschiedenis VO, 1e graads

0,050

0,050

WO Engels

0,050

VMBO algemeen beveiligingsmedewerker

0,050

Huidige of laatste beroep

Nooit gewerkt

0,050

Secretaresse binnen Metaal-sector

0,053

Secretaresse buiten Metaal-sector

0,053

Directiesecretaresse binnen Metaal-sector

0,053

Directiesecretaresse buiten Metaal-sector

0,053

Managementassistent binnen Metaal-sector

0,053

Managementassistent buiten Metaal-sector

0,053

Administratief medewerker binnen Metaal-sector

0,053

Administratief medewerker buiten Metaal-sector

0,053

Medisch secretaresse

0,053

Verkoper detailhandel

0,048

Steward (luchtvaart)

0,048

Zweminstructeur

Medewerker peuterspeelzaal

0,048

Bankemployee

0,048

Caissiere

0,048

Freelance journalist

0,048

Receptionist

0,048

Serveerder

0,048

Schoonmaker

0,048 
Tabel C.19

Fijnbankwerker

kans

Opleiding

MBO Fijnmechanische techniek

0,111

MBO Machinebankwerker fijnmechanisch (LLW)

0,111

MBO Gereedschapsmaker (LLW)

0,111

MBO Instrumentmaker (LLW)

0,111

MBO Graveur (LLW)

0,111

MBO Research-instrumentmaker Metaal

0,111

IVBO Fijnmetaalbewerken

0,024

IVBO Mechanische techniek

0,024

VBO Constructiebankwerker

0,024

VBO Mechanische techniek

0,024

MBO Constructiebankwerker/lasser (LLW)

0,024

MBO Machinaal verspaner

0,024

MBO Machinaal verspaner (LLW)

0,024

MBO Plaatwerker (LLW)

MBO Uurwerktechnicus

0,024

HBO Werktuigbouwkunde

0,024

0,024

MAVO

0,024

HAVO

0,024

MBO Vliegtuigbouwer (LLW)

0,024

HBO Computertechniek

0,024

Huidige of laatste beroep

Nooit gewerkt

0,050

Fijnbankwerker

0,158

Gereedschapmaker

0,158

Uurwerkmaker

0,158

Gereedschapsmid

0,158

Lasser

0,024

Constructie- en apparatenbouwer $\quad 0,024$

Constructiebankwerker

0,024

Machinebankwerker

0,024

Edelmetaalbewerker

0,024

Lasinspecteur

0,024

Eerste monteur industrieel onderhoud

0,024

Machinaal verspaner

0,024

Postbesteller

0,024

Vakkenvuller

0,024

Vuilnisman

0,024

Caissiere

0,024

Schoonmaker

0,024 
Tabel C.20

Productiemedewerker

kans

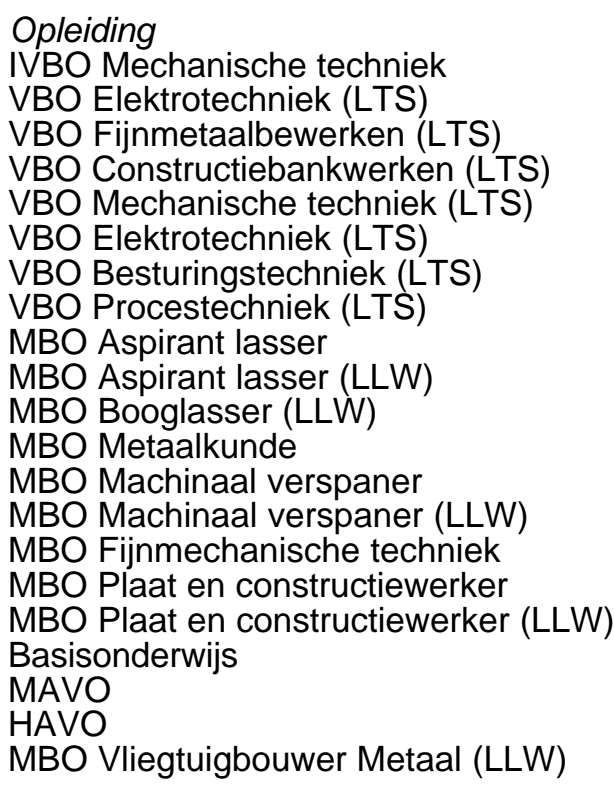

Huidige of laatste beroep

Nooit gewerkt

Productiemedewerker metaalbedrijf

Metaalarbeider

0,190

Booglasser

0,050

Aspirant lasser

0,050

Elektrisch booglasser

0,050

Constructiewerker/lasser

0,050

Machinaal verspaner

0,050

Constructiebankwerker

0,050

Constructiebankwerker stalen ramen

0,050

Constructie- en apparatenbouwer

0,050

Eerste monteur industrieel onderhoud

0,050

Pijpmonteur

Fijnbankwerker

0,050

0,050

Metaalgieter

0,050

Postbesteller

0,050

Vakkenvuller

0,050

Vrachtwagechauffeur

0,050

Buschauffeur

0,050

Cassiere

0,050

Vuilnisman

0,050

Schoonmaker

0,050 


\section{Bijlage D: Vragenlijst}

Procedure voor het vignetonderzoek (IT-Sector).

\section{Vooraf}

Noteer voor het bezoek de gegevens onder het kopje algemeen voorzover deze al bekend zijn. Omcirkel de functies waarover het bedrijf ondervraagd gaat worden.

\section{Het bedrijfsbezoek}

1. Voorstellen en bedanken voor medewerking.

2. Uitleggen van de doelstelling van het onderzoek in brede bewoording, en het uitleggen van de procedure. Wijs ze daarbij ook op het feit dat de gegevens vertrouwelijk behandeld zullen worden, en nooit op "bedrijfsniveau" gepubliceerd.

3. De enquêteur krijgt voor maximaal vier functies een stapeltje genummerde vignetten mee, 15 per functie. De bedoeling is dat de geënquêteerde per functie eerst de functiebeschrijving krijgt voorgelegd, en daarna deze 15 vignetten EEN voor EEN, OP NUMMER (van 1 tot 15) aangereikt krijgt en deze dan op volgorde van voorkeur neerlegt. Het op nummer aanreiken van de vignetten is belangrijk voor de analyse!!!!

4. Als de vignetten op volgorde liggen moet er door de geënquêteerde aangegeven worden wat de eerste is die hij/zij niet meer acceptabel vindt voor de functie.

5. Vervolgens vragen: Hoeveel (extra) kosten voor b.v. opleiding zou u moeten maken om deze kandidaat voor $u$ even inzetbaar/aantrekkelijk te maken als de laatste kandidaat die nog wel acceptabel voor $u$ is. (Als geënquêteerde alle kandidaten acceptabel vindt, deze vraag stellen voor de slechtste kandidaat, en deze relateren aan de op een na laatste). Dit kostenbedrag noteren onder kopje algemeen.

6. Vervolgens moeten de vignetten ofwel van een volgnummer voorzien worden (1=best, 15 =slechtst), ofwel zo aan elkaar vast gemaakt worden dat dit nummeren achteraf kan. Genoteerd moet worden het nummer van de eerste niet-acceptabele kandidaat.

$\rightarrow$ Deze procedure moet voor alle vier de functies herhaald worden.

7. Na afloop van dit onderdeel moet vervolgens de vragenlijst afgenomen worden. DOE DIT NIET VOORAF, want dat kan de resultaten beï nvloeden! De vragenlijst wordt mondeling afgenomen en de enquêteur noteert de antwoorden. Voor vraag 8 wordt een kaartje aangereikt.

8. Bedank nogmaals voor medewerking, en geef aan dat ze - als ze daar belangstelling voor hebben, een overzicht van de resultaten voor hun sector kunnen krijgen. 


\section{$\mathrm{Na}$ afloop}

$\mathrm{Na}$ afloop van het interview moeten thuis de resultaten in een excell-spreadsheet ingevoerd worden:

$\Rightarrow \quad$ Per functie een regel (dus vier regels per geënquêteerde) met daarop eerst de antwoorden op de vragen,

$\Rightarrow$ daarna in 15 kolommen het vignetnummer dat het best $t / m$ het slechtst gewaardeerd wordt.

$\Rightarrow \quad$ Ten slotte het vignetnummer (niet het volgnummer) dat niet meer acceptabel is. 


\section{Algemeen}

Enquêteur

Bedrijf:

Naam contactpersoon: $\mathrm{dhr} / \mathrm{mevr}^{*}$

tel.nr.:

Sector: IT

Functies:

1. Helpdeskmedewerker

Volgnummer vignet (tweede nummer)

2. Secretaresse/managementassistente

3. Programmeur

4. Projectmanager

5. Projectadviseur

6. Systeemontwerper

Datum enquête:

Duur enquête:

\section{Subsidie}

1. Helpdeskmedewerker

2. Secretaresse/managementassistente

3. Programmeur

4. Projectmanager

5. Projectadviseur

6. Systeemontwerper

*) omcirkelen wat van toepassing is 


\section{Vragenlijst}

1. Hoeveel werknemers heeft dit bedrijf? (indien het bedrijf meerdere vestigingen heeft dan alleen de werknemers in deze vestiging meetellen)

2. Is het aantal werknemers de afgelopen 12 maanden toegenomen, gelijk gebleven of afgenomen?

3. Verwacht $u$ dat het aantal werknemers de komende 12 maanden zal toenemen, gelijkblijven of afnemen?

4. Wat is de leeftijd van dit bedrijf?

$\rightarrow \quad$ Vraag 5 alleen voor omcirkelde functies vragen

5. Hoeveel mensen zijn in dit bedrijf werkzaam als:

(Indien niet exact bekend laat dan een schatting maken!)

(1) helpdeskmedewerker?

(2) secretaresse/managementassistente?

(3) programmeur?

(4) projectmanager?

(5) projectadviseur?

(6) systeemontwerper?

$\rightarrow \quad$ Vraag 6 alleen voor omcirkelde functies vragen

6. Hoeveel vacatures zijn er op dit moment bij dit bedrijf voor:

(1) helpdeskmedewerker?

(2) secretaresse/managementassistente?

(3) programmeur?

(4) projectmanager?

(5) projectadviseur?

(6) systeemontwerper?

$\rightarrow \quad$ Vraag 7 alleen voor omcirkelde functies vragen

$\rightarrow \quad$ Omcirkel de juiste antwoordcategorie

7. Is het momenteel moeilijk om vacatures vervuld te krijgen voor

(1) helpdeskmedewerker?

zeer redelijk redelijk zeer moeilijk moeilijk makkelijk makkelijk

(2) secretaresse/managementassistente?

1

(3) programmeur?

(4) projectmanager?

(5) projectadviseur?

(6) systeemontwerper?

2
2
2
2
2
2

3

4

$3 \quad 4$

34

34

34

34


$\rightarrow \quad$ Vraag 8 alleen voor omcirkelde functies vragen

8. Leidt uw bedrijf werknemers op voor:

(1) helpdeskmedewerker?

(2) secretaresse/managementassistente?

(3) programmeur?

(4) projectmanager?

(5) projectadviseur?

(6) systeemontwerper?

9. Wat doet $u$ als u uw vacatures niet met geschikte kandidaten vervuld krijgt? meerdere antwoordcategorieën mogelijk
a. de selectiecriteria aanpassen
b. zelf personeel opleiden
c. de functie opsplitsen
d. anders, namelijk ...

\section{Overhandig geënquêteerde het kaartje}

10. Kunt $u$ in volgorde aangeven hoe belangrijk de volgende selectiecriteria voor $u$ zijn? ( $1=$ het belangrijkst, $5=$ minst belangrijk)
a. leeftijd
b. geslacht
c. werkervaring
d. opleidingsachtergrond
e. hobby's

11. Dan wil ik u graag nog enkele gegevens over u zelf vragen:
a. Wat is uw functie in dit bedrijf?
b. Wat is uw leeftijd?
c. Welke opleidingsachtergrond heeft $u$ ?
d. Hoelang bent u bij dit bedrijf werkzaam?

12. Heeft u nog opmerkingen die voor ons relevant zouden kunnen zijn?

Dank voor uw medewerking! 
Kunt $u$ in volgorde aangeven hoe belangrijk de volgende selectiecriteria voor $u$ zijn? ( $1=$ het belangrijkst, $5=$ minst belangrijk)
a. leeftijd
b. geslacht
c. werkervaring
d. opleidingsachtergrond
e. hobby's 